\title{
Observed and simulated global distribution and budget of atmospheric $\mathrm{C}_{2}-\mathrm{C}_{5}$ alkanes
}

\author{
A. Pozzer ${ }^{1,2}$, J. Pollmann ${ }^{2}$, D. Taraborrelli ${ }^{2}$, P. Jöckel ${ }^{2,}$, D. Helmig ${ }^{3}$, P. Tans ${ }^{4}$, J. Hueber ${ }^{3}$, and J. Lelieveld ${ }^{1,2}$ \\ ${ }^{1}$ The Cyprus Institute, Energy, Environment and Water Research Center, P. O. Box 27456, 1645 Nicosia, Cyprus \\ ${ }^{2}$ Air Chemistry Department, Max-Planck Institute of Chemistry, P. O. Box 3060, 55020 Mainz, Germany \\ ${ }^{3}$ Institute of Arctic and Alpine Research (INSTAAR), University of Colorado, UCB 450, CO 80309, USA \\ ${ }^{4}$ NOAA/ESRL, 325 Broadway, Boulder, CO 80303, USA \\ *now at: DLR, Institut fuer Physik der Atmosphaere, Oberpfaffenhofen, 82234 Wessling, Germany
}

Received: 7 December 2009 - Published in Atmos. Chem. Phys. Discuss.: 13 January 2010

Revised: 23 April 2010 - Accepted: 26 April 2010 - Published: 12 May 2010

\begin{abstract}
The primary sources and atmospheric chemistry of $\mathrm{C}_{2}-\mathrm{C}_{5}$ alkanes were incorporated into the atmospheric chemistry general circulation model EMAC. Model output is compared with new observations from the NOAA/ESRL GMD Cooperative Air Sampling Network. Based on the global coverage of the data, two different anthropogenic emission datasets for $\mathrm{C}_{4}-\mathrm{C}_{5}$ alkanes, widely used in the modelling community, are evaluated. We show that the model reproduces the main atmospheric features of the $\mathrm{C}_{2}-\mathrm{C}_{5}$ alkanes (e.g., seasonality). While the simulated values for ethane and propane are within a $20 \%$ range of the measurements, larger deviations are found for the other tracers. According to the analysis, an oceanic source of butanes and pentanes larger than the current estimates would be necessary to match the observations at some coastal stations. Finally the effect of $\mathrm{C}_{2}-\mathrm{C}_{5}$ alkanes on the concentration of acetone and acetaldehyde are assessed. Their chemical sources are largely controlled by the reaction with $\mathrm{OH}$, while the reactions with $\mathrm{NO}_{3}$ and $\mathrm{Cl}$ contribute only to a little extent. The total amount of acetone produced by propane, $i$-butane and $i$-pentane oxidation is $11.2 \mathrm{Tg} / \mathrm{yr}, 4.3 \mathrm{Tg} / \mathrm{yr}$, and $5.8 \mathrm{Tg} / \mathrm{yr}$, respectively. Moreover, 18.1, 3.1, 3.4, 1.4 and $4.8 \mathrm{Tg} / \mathrm{yr}$ of acetaldehyde are formed by the oxidation of ethane, propane, $n$-butane, $n$-pentane and $i$-pentane, respectively.
\end{abstract}

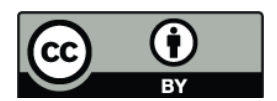

Correspondence to: A. Pozzer

(pozzer@cyi.ac.cy)

\section{Introduction}

Non Methane Hydrocarbons (NMHC) play an important role in tropospheric chemistry and ozone formation. They significantly influence the hydroxyl radical $\mathrm{HO}_{\mathrm{x}}\left(=\mathrm{OH}+\mathrm{HO}_{2}\right)$ budget through many complex reaction cycles (Logan, 1985; Houweling et al., 1998; Seinfeld and Pandis, 1997; Atkinson, 2000). For example, NMHC are precursors of the formation of oxygenated volatile organic compounds (OVOC) such as acetone, formaldehyde and acetaldehyde. The seasonal and spatial distribution of NMHC is determined by:

- emission strength (Singh et al., 2001, 2003; Singh and Zimmermann, 1992),

- photochemical reactions (Cardelino and Chameides, 1990; Singh et al., 1995; Neeb, 2000),

- atmospheric transport (Rood, 1987; Brunner et al., 2003),

- dilution due to atmospheric mixing (Roberts et al., 1985; Parrish et al., 2007).

Three-dimensional (3-D) global models, which represent both transport and chemical processes, allow to study and predict the spatial distribution and the temporal development of these species (Gupta et al., 1998; Roelofs and Lelieveld, 2000; Poisson et al., 2000; von Kuhlmann et al., 2003b; Folberth et al., 2006). Here we compare results of the EMAC (ECHAM5/MESSy1 Atmospheric Chemistry) model with data based on flask measurements (see Sect. 3) collected at

Published by Copernicus Publications on behalf of the European Geosciences Union. 
remote locations across the globe during the years 20052008. The NMHC flask measurements (Pollmann et al., 2008) include ethane $\left(\mathrm{C}_{2} \mathrm{H}_{4}\right)$, propane $\left(\mathrm{C}_{3} \mathrm{H}_{8}\right)$, butane (or $n$-butane, $\mathrm{n}-\mathrm{C}_{4} \mathrm{H}_{10}$ ), isobutane (or $i$-butane, $\mathrm{i}-\mathrm{C}_{4} \mathrm{H}_{10}$ ), pentane (or $n$-pentane, $\mathrm{n}-\mathrm{C}_{5} \mathrm{H}_{12}$ ) and isopentane (or $i$-pentane, i- $\left.\mathrm{C}_{5} \mathrm{H}_{12}\right)$.

In Sect. 2 the model is presented: two simulations (E1 and E2), based on two different emission databases for butanes (i.e. $n$-butane plus $i$-butane) and pentanes (i.e. $n$-pentane plus $i$-pentane), are described. Then, the observational data set (Sect. 3) is described, followed by a comparison between model results and observations (Sect. 4). Finally, we discuss the contribution of $\mathrm{C}_{2}-\mathrm{C}_{5}$ alkanes to the atmospheric production and mixing ratios of the most important OVOC (Sect. 5), with a focus on the acetone budget.

\section{Model description and setup}

EMAC is a combination of the general circulation model ECHAM5 (Roeckner et al., 2006) (version 5.3.01) and the Modular Earth Submodel System (MESSy, version 1.1, Jöckel et al., 2005). Descriptions of the model system were published by Jöckel et al. (2006) and Pozzer et al. (2007). Details about the model system can be found at http://www.messy-interface.org. The setup is based on that of the evaluation simulation S1, described by Jöckel et al. (2006). It was modified by adding the emissions of butane and pentane isomers, and their corresponding oxidation pathways (see Sect. 2.1 and Sect. 2.2).

The simulation period covers the years 2005-2008, plus two additional months of spin-up time. The initial conditions are taken from the evaluation simulation $\mathrm{S} 1$ of the model. Dry and wet deposition processes are described by Kerkweg et al. (2006a) and Tost et al. (2006), respectively; the tracer emissions are described by Kerkweg et al. (2006b). As in the simulation S1, the applied spectral truncation of the ECHAM5 base model is T42, corresponding to an horizontal resolution of $\approx 2.8^{\circ} \times 2.8^{\circ}$ of the quadratic Gaussian grid. The applied vertical resolution is 90 layers, with about 25 levels in the troposphere. The model setup includes feedbacks between chemistry and dynamics via radiation calculations. The model dynamics was weakly nudged (Jeuken et al., 1996; Jöckel et al., 2006; Lelieveld et al., 2007) towards the analysis data of the ECMWF (European Center Medium-range Weather Forecast) operational model (up to $100 \mathrm{hPa}$ ) to realistically represent the tropospheric meteorology of the selected period. This implies that the general circulation model is following the meteorology (at synoptic scale) as assimilated by the ECMWF analysis, which takes advantage of more than 75 million observations in a $12 \mathrm{~h}$ period (98\% of them are from satellites). We refer to the ECMWF (http://www.ecmwf.int) for further information. The uncertainties connected with the weak nudging (or better, due to the internal variability of the model which remains despite the nudging) can be estimated by the differences of meteorological parameters between the two simulations. This has already been discussed in a previous study (Pozzer et al., 2009), where differences of $\sim 15 \%$ were found between two different simulations for temperature and relative humidity. It must be stressed, however, that the usage of monthly averages drastically decreases the uncertainties arising from the differences in the meteorology. As estimated by Pozzer et al. (2009), the differences in the temperature and relative humidity are below $5 \%$ if monthly averages are considered. It is hence expected to reproduce the meteorology assimilated by the ECMWF analysis, allowing a direct comparison of model results with observations. Nevertheless, for the overall representation of the real meteorology, we rely on the ECMWF data assimilation, which has been evaluated previously (see for example Bozzano et al. (2004) or Salstein et al. (2008) for comparisons with surface observations). Following Bozzano et al. (2004), for temperature, pressure and humidity, a low relative difference between ECMWF analysis data and measurements is observed, while for the wind speed a relative difference of up to $100 \%$ was determined from the comparison of model output and observations. These uncertainties do not translate directly into uncertainties in the simulated alkane mixing ratios, due to the non-linearity of the system. In addition, errors in estimating different meteorological parameters have different direct/indirect effects on the simulated chemistry of alkanes. Nevertheless, Bozzano et al. (2004) also showed that when long time averages are considered (as in this study), the differences are much lower. Therefore an upper threshold of $\sim 100 \%$ is estimated for the uncertainty in the simulated alkane concentrations.

\subsection{Chemistry}

The chemical kinetics within each grid-box was calculated with the submodel MECCA (Sander et al., 2005). The set of chemical equations solved by the Kinetic PreProcessor (KPP, Damian et al. (2002); Sandu et al. (2003); Daescu et al. (2003), see http://people.cs.vt.edu/ asandu/Software/Kpp/) in this study was essentially the same as in Jöckel et al. (2006). However, the propane oxidation mechanism (which was already included in the original chemical mechanism) was slightly changed, and new reactions for the butane and pentane isomers were added.

The complete list of differences from the original chemical mechanism used in Jöckel et al. (2006) is presented in the electronic supplement (see http://www.atmos-chem-phys. net/10/4403/2010/acp-10-4403-2010-supplement.pdf). The new reactions are a reduction of the corresponding detailed Master Chemical Mechanism (MCM, Saunders et al., 2003). In order to keep the number of reactions as low as possible for 3-D global simulations, the first generation products of the reactions of butanes and pentanes with $\mathrm{OH}$, $\mathrm{NO}_{3}$, and $\mathrm{Cl}$ were directly substituted with their final degradation products formaldehyde, acetaldehyde and acetone. 
This substitution includes the production of corresponding amounts of a model peroxy radical $\left(\mathrm{RO}_{2}\right)$, which has generic properties representing the total number of $\mathrm{RO}_{2}$ produced during the "instantaneous oxidation". With this approach we take into account the $\mathrm{NO} \rightarrow \mathrm{NO}_{2}$ conversions and the $\mathrm{HO}_{2}$ $\rightarrow \mathrm{OH}$ interconversion. It is assumed that the reactions with $\mathrm{OH}$ and $\mathrm{NO}_{3}$ have the same product distribution. The $\mathrm{Cl}$ distribution was nudged with monthly average mixing ratios taken from Kerkweg et al. (2008a,b, and references therein). Thus, both alkanes and $\mathrm{Cl}$ are simulated without the need of a computationally expensive chemical mechanism. Small uncertainties in the model simulation have to be attributed to the reaction rates used in this study. Nevertheless, according to the IUPAC (International Union of Pure and Applied Chemistry) recommendation for butanes and pentanes, the uncertainties in the reaction rates are on the order of $7 \%$. Moreover, the chemical mechanism itself does not increase the uncertainties in the simulation of $\mathrm{C}_{4}-\mathrm{C}_{5}$ alkanes, but only those of their products, due to the simplified degradation reactions.

Finally, the $\mathrm{OH}$ concentration is very important for a correct simulation of NMHC. Jöckel et al. (2006) performed a detailed evaluation of the simulated $\mathrm{OH}$ abundance. In summary, $\mathrm{OH}$ compared very well with that of other models of similar complexity. Compared to Spivakovsky et al. (2000), the EMAC simulation of $\mathrm{OH}$ indicated slightly higher values in the lower troposphere and lower values in the upper troposphere. We refer to Jöckel et al. (2006) for further details.

\subsection{Emissions}

\subsubsection{Anthropogenic emissions}

As pointed out by Jobson et al. (1994) and Poisson et al. (2000), the seasonal change in the anthropogenic emissions of NMHC are thought to be small, due to their relatively constant release from fossil fuel combustion and leakage from oil and natural gas production (Middleton et al., 1990; Blake and Rowland, 1995; Friedrich and Obermeier, 1999). The most detailed global emission inventory available is EDGAR (Olivier et al., 1999, 1996; van Aardenne et al., 2001), Emission Database for Global Atmospheric Research, which was applied for the evaluation simulations of EMAC (Jöckel et al., 2006).

In the evaluation simulation "S1" of the model (Jöckel et al., 2006), the anthropogenic emissions were taken from the EDGAR database (version 3.2 "fast-track", van Aardenne et al., 2005) for the year 2000. In order to keep the simulations as consistent as possible with the evaluation simulation S1, the ethane and propane emissions were not changed and annual global emissions of 9.2 and $10.5 \mathrm{Tg} / \mathrm{yr}$ respectively, as reported by Pozzer et al. (2007), were applied. Furthermore, the total butanes and pentanes emissions from EDGARv2.0 were used, i.e. $14.1 \mathrm{Tg} / \mathrm{yr}$ and $12.3 \mathrm{Tg} / \mathrm{yr}$, respectively. The simulation with these emissions for butanes
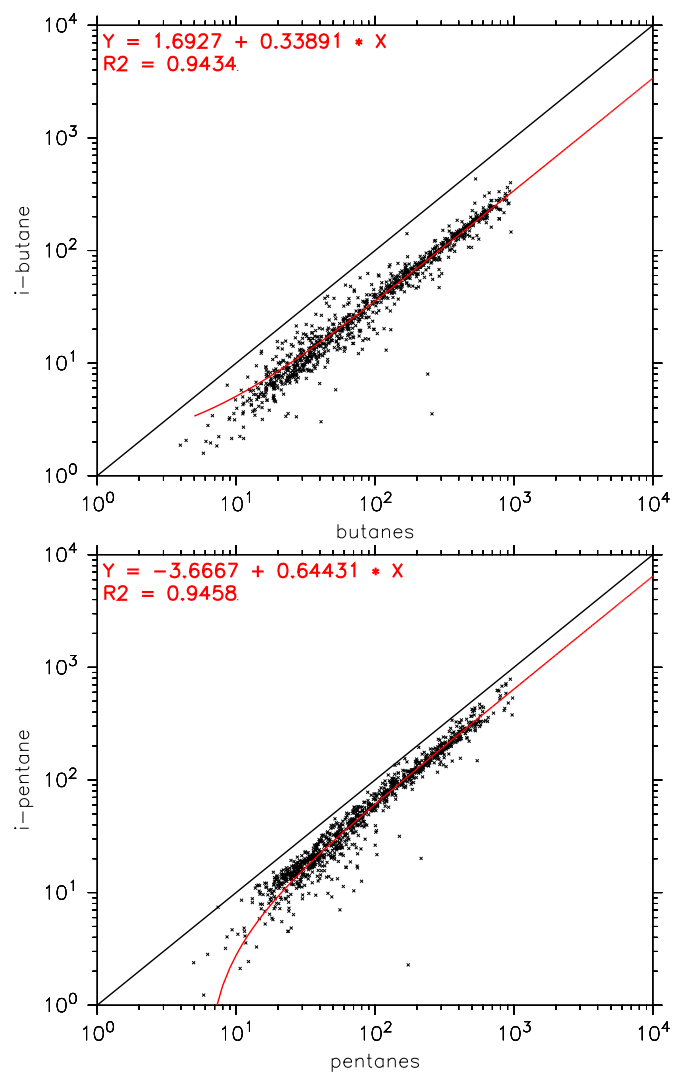

Fig. 1. $i$-butane versus butanes (upper figure) and $i$-pentane versus pentanes (lower figure) measurements in $\mathrm{pmol} / \mathrm{mol}$. The black line represents the 1 to 1 line, while the red line represent the linear regression of the data. In the upper left corner the regression parameters are presented. Note the logarithmic scale of the axes.

and pentanes is further denoted as "E1". Based on speciation factors described below, the total emissions are $9.9 \mathrm{Tg} / \mathrm{yr}$ for $n$-butane (70\% of all butanes), $4.2 \mathrm{Tg} / \mathrm{yr}$ for $i$-butane $(30 \%$ of all butanes), $4.3 \mathrm{Tg} / \mathrm{yr}$ for $n$-pentane ( $35 \%$ of all pentanes) and $8.0 \mathrm{Tg} / \mathrm{yr}$ for $i$-pentane (65\% of all pentanes).

It must be stressed that the EDGAR database has been criticized for the inaccuracies in the $\mathrm{C}_{4}-\mathrm{C}_{5}$ alkane emissions. As pointed out by Jacob et al. (2002), “... the EDGAR inventory underestimates considerably the observed atmospheric concentration of propane and $i$-butane over Europe, over the United States and downwind Asia". Based on these considerations, Jacob et al. (2002) suggested a different emission inventory distribution, as described by Bey et al. (2001). From this distribution, Jacob et al. (2002) estimated a total of $10.15,4.35,3.2$ and $6.0 \mathrm{Tg} / \mathrm{yr}$ emission of $n$-butane, $i$ butane, $n$-pentane and $i$-pentane respectively, with the same isomer speciacion factors used before. To evaluate which emissions database describes butanes and pentanes most realistically, an additional simulation (denoted "E2") was performed, using the butanes and pentanes emission distributions as suggested by Bey et al. (2001). The total butane 
Table 1. Summary of the emissions used in simulation S1, E1 and E2 in $\mathrm{Tg}$ (species)/yr.

\begin{tabular}{llccccccc}
\hline simulation & emission type & $\mathrm{C}_{2} \mathrm{H}_{6}$ & $\mathrm{C}_{3} \mathrm{H}_{8}$ & $\mathrm{n}_{-} \mathrm{C}_{4} \mathrm{H}_{10}$ & $\mathrm{i}-\mathrm{C}_{4} \mathrm{H}_{10}$ & $\mathrm{n}-\mathrm{C}_{5} \mathrm{H}_{12}$ & i- $\mathrm{C}_{5} \mathrm{H}_{12}$ & higher alkanes \\
\hline \multirow{2}{*}{$\mathrm{S} 1$} & anthropogenic & $9.2^{\mathrm{b}}$ & $10.5^{\mathrm{b}}$ & - & - & - & - & 73.7 \\
& biomass burning & $2.8^{\mathrm{e}}$ & $0.9^{\mathrm{e}}$ & - & - & - & - & 1.1 \\
& oceanic & $0.5^{\mathrm{d}}$ & $0.3^{\mathrm{d}}$ & - & - & - & - & 0.4 \\
$\mathrm{E} 1$ & anthropogenic & $9.2^{\mathrm{b}}$ & $10.5^{\mathrm{b}}$ & $9.9^{\mathrm{c}}$ & $4.2^{\mathrm{c}}$ & $4.3^{\mathrm{c}}$ & $8.0^{\mathrm{c}}$ & 47.3 \\
& biomass burning & $2.8^{\mathrm{e}}$ & $0.9^{\mathrm{e}}$ & - & - & - & - & 1.1 \\
& oceanic & $0.5^{\mathrm{d}}$ & $0.3^{\mathrm{d}}$ & - & - & - & - & 0.4 \\
$\mathrm{E} 2$ & anthropogenic & $9.2^{\mathrm{b}}$ & $10.5^{\mathrm{b}}$ & $10.1^{\mathrm{a}}$ & $4.3^{\mathrm{a}}$ & $4.3^{\mathrm{a}}$ & $8.0^{\mathrm{a}}$ & 46.9 \\
& biomass burning & $2.8^{\mathrm{e}}$ & $0.9^{\mathrm{e}}$ & - & - & - & - & 1.1 \\
& oceanic & $0.5^{\mathrm{d}}$ & $0.3^{\mathrm{d}}$ & - & - & - & - & 0.4 \\
\hline
\end{tabular}

${ }^{\mathrm{a}}$ with emissions distribution from Bey et al. (2001);

b based on EDGARv3.2, fast-track 2000;

$\mathrm{c}$ based on EDGARv2.0;

d based on Plass-Dülmer et al. (1995);

e based on Van der Werf et al. (2004) and Andreae and Merlet (2001) for the year 2000 (see Sect. 2.2.2).

emissions used in simulation E2 is the one estimated by Jacob et al. (2002). Differently, for pentanes, the total emission estimated by Jacob et al. (2002) significantly underestimates the observed mixing ratios of these tracers in a sensitivity simulation (not shown). Hence, the total amount of pentanes used in simulation E2 was scaled to $12.3 \mathrm{Tg} / \mathrm{yr}$, the same total amount of the EDGARv2.0 database. In conclusion, the total amounts emitted in simulation E2 are 10.35, 4.35, 4.3, 8.0 Tg/yr for $n$-butane, $i$-butane, $n$-pentane and $i$-pentane, respectively. The emissions used in simulation S1, E1 and E2 are summarized in Table 1. The two emission sets, although with very similar total emissions of butanes and pentanes, present very different spatial distributions. The differences in a single grid box can be up to a factor of 4 , depending on the location.

The speciacion fractions used for $i$-butane $(30 \%)$ and $n$ butane (70\%), and for $i$-pentane $(65 \%)$ and $n$-pentane $(35 \%)$ are from the calculation of Saito et al. (2000) and Goldan et al. (2000), respectively. These fractions have been confirmed by McLaren et al. (1996), who showed that the ratio of $n$-pentane to $i$-pentane is 0.5 (i.e. a fraction of $\sim 66 \%$ for $i$-pentane and $\sim 34 \%$ for $n$-pentane over pentanes). The long-term measurements from the NOAA flask data set also confirm these speciacion factors. Measurements from the database are shown in Fig. 1, with the exception of data with very high uncertainties, i.e. observations of mixing ratios lower than $1 \mathrm{pmol} / \mathrm{mol}$ or larger than $1000 \mathrm{pmol} / \mathrm{mol}$. As shown in Fig. 1, the fraction of $i$-butane of the butanes is $\sim 0.33$, while the fraction of $i$-pentane of the pentanes is $\sim 0.65$. These values are in close agreement with the speciacion factors present in the literature.

\subsubsection{Biomass burning}

Biomass burning is a large source of ethane and propane, and a negligible source of butane and pentane isomers (Andreae and Merlet, 2001; Guenther et al., 2000). Blake et al. (1993) extrapolated the total emission from biomass burning of $1.5 \mathrm{Tg} / \mathrm{yr}$ for ethane, and $0.6 \mathrm{Tg} / \mathrm{yr}$ for propane. Rudolph (1995) suggested instead $6.4 \mathrm{Tg} / \mathrm{yr}$ for ethane. The biomass burning contribution was added using the Global Fire Emissions Database (GFED version 1, Van der Werf et al., 2004) for the year 2000 (neglecting interannual variability) scaled with different emissions factors (Andreae and Merlet, 2001; von Kuhlmann et al., 2003a). The total amounts calculated are $2.76 \mathrm{Tg} / \mathrm{yr}$ and $0.86 \mathrm{Tg} / \mathrm{yr}$ for ethane and propane, respectively. No biomass burning emission was included for $\mathrm{C}_{4}-\mathrm{C}_{5}$ alkanes, due to small contribution to the global budget of these tracers.

\subsubsection{Biogenic emissions}

Biogenic sources of $\mathrm{C}_{2}-\mathrm{C}_{5}$ alkanes appear to be negligibly small (Kesselmeier and Staudt, 1999; Guenther et al., 1995). Other measurements in rural environments (Jobson et al., 1994; Goldan et al., 1995) show no evidence of biogenic emissions of saturated $\mathrm{C}_{2}-\mathrm{C}_{5} \mathrm{NMHC}$.

\subsubsection{Oceanic emissions}

Alkanes are also emitted by the oceans. Plass-Dülmer et al. (1995) estimated $1 \mathrm{Tg} / \mathrm{yr}$ as upper limit for the global emission of $\mathrm{C}_{2}-\mathrm{C}_{4}$ alkanes: $0.54 \mathrm{Tg} / \mathrm{yr}$ of ethane, $0.35 \mathrm{Tg} / \mathrm{yr}$ of propane and $0.11 \mathrm{Tg} / \mathrm{yr}$ of butanes ( $n$-butane $+i$-butane). Broadgate et al. (1997) extrapolated global oceanic emissions to $0.04 \mathrm{Tg} / \mathrm{yr}$ for $i$-butane, $0.17 \mathrm{Tg} / \mathrm{yr}$ for $n$-butane, $0.03 \mathrm{Tg} / \mathrm{yr}$ for $i$-pentane, and $0.06 \mathrm{Tg} / \mathrm{yr}$ for $n$-pentane. 
While oceanic emissions for ethane and propane were included in this study, oceanic emissions of higher alkanes were neglected due to their small contribution and largely unknown spatio-temporal distribution.

\subsubsection{Other sources}

Etiope and Ciccioli (2009) proposed a geophysical (volcanic) source of ethane and propane. Based on observations of gas emissions from volcanoes, they estimated emissions of 2 to $4 \mathrm{Tg} / \mathrm{yr}$ for ethane and of 1 to $2.4 \mathrm{Tg} / \mathrm{yr}$ for propane. However, since the emission distribution is unknown, it is not yet feasible to include this source into the model. In addition, results from our simulations do not support a further increase in the emissions of these species (see below, Sects. 4.1-4.2).

\section{Observations}

The NOAA ESRL GMD (National Oceanic and Atmospheric Administration, Earth System Research Laboratory, Global Monitoring Division, Boulder, CO, USA) cooperative air sampling network currently includes 59 active surface sampling stations, where usually one pair of flask samples is collected every week. This network is the most extensive global flask sampling network in operation, both in terms of number of sites and total number of samples collected. NMHC data are available from approximately 40 of these sampling stations (see http://www.esrl.noaa.gov/gmd/), covering the latitudes from $82^{\circ} \mathrm{N}$ (ALT, Alert, Canada) to $89.98^{\circ} \mathrm{S}$ (SPO, South Pole). However, the measurements collected from the stations are not homogeneously distributed in time and some gaps are present in the data. A variable number of measurements were used to calculate the monthly averages here. The monthly variability was calculated as the monthly standard deviation of the measurements. As pointed out by Haas-Laursen and Hartley (1997), these flask samples have been collected under non-polluted conditions, i.e., for stations close to local sources only certain wind directions were selected to avoid local contamination. Moreover, most of the stations are in remote regions, where background conditions are sampled. It is hence expected that the model resolution used in this study is sufficient to reproduce the chemical history of the $\mathrm{C}_{2}-\mathrm{C}_{5}$ alkanes, while higher resolution simulations would be required for studying specific stations, as example in industrialized areas or where sporadic biomass burning emissions are important (see below Sect. 4.7).

A detailed description of the flask instrument and a full evaluation of the analytical technique was published by (Pollmann et al., 2008). An intercomparison with the WMO GAW (World Meteorological Organization, Global Atmospheric Watch) station in Hohenpeissenberg, Germany showed that flask measurements meet the WMO data quality objective (World Meteorological Organization, 2007). These findings were confirmed during a recent audit by the World
Calibration Center for Volatile Organic Compound (WCCVOC, http://imk-ifu.fzk.de/wcc-voc/).

\section{Comparison of the model results with observations}

In this section only time series from a selected number of sites are presented. The complete set of figures can be found in the electronic supplement of this paper (see http://www.atmos-chem-phys.net/10/4403/2010/ acp-10-4403-2010-supplement.pdf).

The seasonal cycle of NMHC exhibits a maximum corresponding to the local winter and a minimum corresponding to the local summer, confirming previous studies by Gautrois et al. (2003); Lee et al. (2006); Swanson et al. (2003). In fact, Hagerman et al. (1997) and Sharma et al. (2000) showed that the seasonal cycle of $\mathrm{C}_{2}-\mathrm{C}_{5}$ alkanes is anti-correlated with the production rate of the main atmospheric oxidant $(\mathrm{OH}$, see Spivakovsky et al., 2000; Jöckel et al., 2006). The flask measurements used in this study confirm this and the model is able to reproduce the observed seasonal signal, with high mixing ratios during winter and low mixing ratios during summer. In addition, due to the small contribution of $\mathrm{C}_{4}-\mathrm{C}_{5}$ alkanes to the total $\mathrm{OH}$ sink (less than $\sim 10 \%$ ), both simulations $\mathrm{E} 1$ and $\mathrm{E} 2$, reproduce the $\mathrm{OH}$ mixing ratios simulated in the reference simulation S1, with local instantaneous differences below $\sim 15 \%$. When monthly averages are considered for $\mathrm{OH}$, the maximum differences between simulation $\mathrm{S} 1$ and simulation $\mathrm{E} 1$ are below $\sim 5 \%$, while the differences between simulation E1 and simulation E2 are below $\sim 2 \%$. For ethane and propane, the same sources (emissions), sinks $(\mathrm{OH})$ and transport (thanks to the nudging) are then applied in both simulations E1 and E2. Although the results for these two tracers are not binary identical in the two simulations, they show only negligible differences, which are not statistically significant. Hence, for ethane and propane, only results from the simulation E1 are shown. On contrary, results from both simulations are presented for butanes and pentanes.

In order to quantify the differences between simulation E1 and E2 with respect to the observations, we calculated the main statistical quantities and resume them in Taylor diagrams (Taylor, 2001). The diagrams (one for each $\mathrm{C}_{4}-\mathrm{C}_{5}$ species) show at a glance the location (latitude) of the stations (color code) and the different simulations (symbol). Moreover, the correlations and biases between the simulations and observations have been weighted by the geometric mean of model variability (standard deviation from the averaged output values) and measurement variability (monthly standard deviation of the measurements from their average). For further details of this approach, we refer to Jöckel et al. (2006, Appendix D). This weighting preserves the relationship between the three statistical quantities visualised in the Taylor diagram. However, locations with a high variability, i.e., where absolute differences are less significant since single measurements are less representative, have less 

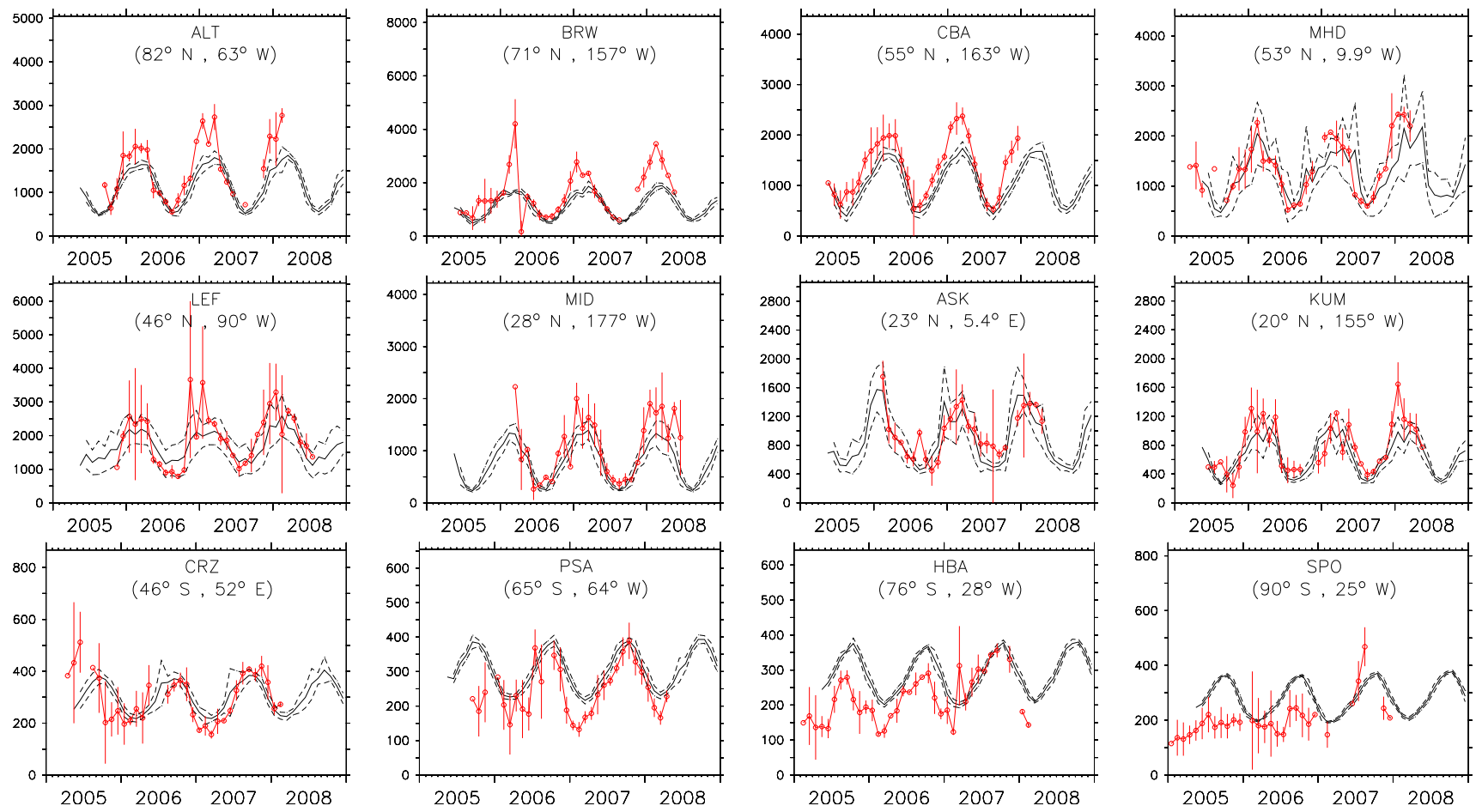

Fig. 2. Comparison of simulated and observed $\mathrm{C}_{2} \mathrm{H}_{6}$ mixing ratios in pmol/mol for some selected locations (ordered by latitude). The red lines and the bars represent the monthly averages and variability (calculated as the monthly standard deviations) of the measurements. The simulated monthly averages are indicated by the black lines and the corresponding simulated monthly variability (calculated as the monthly standard deviations of the simulated mixing ratios) by the dashed lines. The three letters at the center of each plot denote the station code (see http://www.esrl.noaa.gov/gmd/ccgg/flask.html). Note the different scales of the vertical axes.

weight. Values which are more representative for the average conditions are weighted stronger, thus suppressing specific episodes that cannot be expected to be reproduced by the model.

Generally, there is a much better agreement between the model simulations and the observations in the Northern Hemisphere (NH) extratropics than in the Southern Hemisphere (SH) extratropics, and the deviation from the observations is largest in the tropics.

\subsection{Ethane, $\mathrm{C}_{2} \mathrm{H}_{6}$}

In Fig. 2 a comparison of the observations and the model simulation is shown for a number of locations. Notice that the seasonal cycle is correctly reproduced, although the model simulates a too low mixing ratio of ethane during the Northern Hemisphere (NH) winter (e.g., Alert, Canada, ALT, and Barrow, Alaska, BRW). On the other hand, the $\mathrm{NH}$ summer mixing ratios are reproduced correctly within the model/observation monthly variability (calculated as the monthly standard deviation of the observations). In the Southern Hemisphere ( $\mathrm{SH}$ ) the results are more difficult to interpret. Although the southern extratropics seem to be well simulated (see CRZ, Crozet Island, France), for polar sites (for example HBA, Halley Station, Antarctica) the model tends to simulate higher mixing ratios than observed. Fig. 3

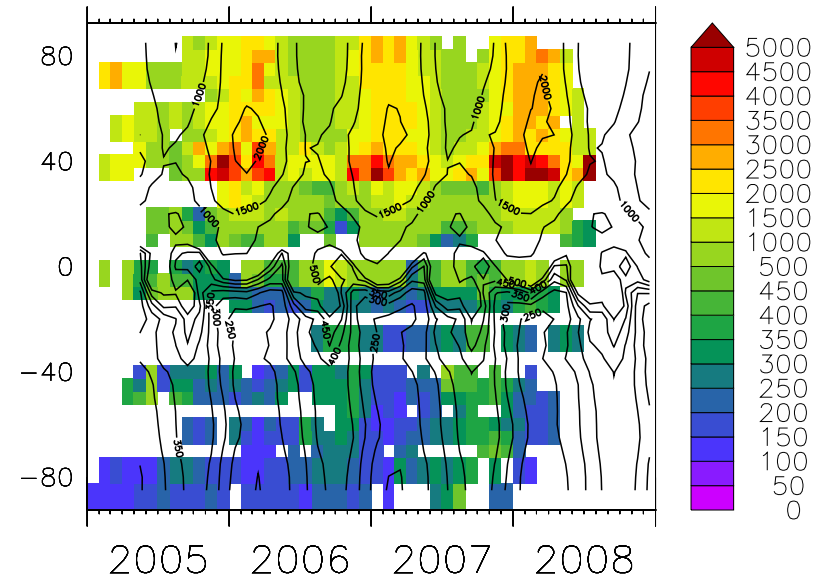

Fig. 3. Seasonal cycle and latitudinal distribution of ethane $\left(\mathrm{C}_{2} \mathrm{H}_{6}\right)$. The colour code denotes the mixing ratios in $\mathrm{pmol} / \mathrm{mol}$, calculated as a zonal average of the measurements available in the NOAA/ESRL GMD dataset. The superimposed contour lines denote the zonal averages of the model results. 
shows the latitudinal gradients and the seasonal cycle from observations and as calculated by the model. The model is able to reproduce the latitudinal mixing ratio changes, including the strong north-south gradient during all seasons.

\subsection{Propane, $\mathrm{C}_{3} \mathrm{H}_{8}$}

As also shown in a previous analysis (Pozzer et al., 2007), the model simulation reproduces the main features observed for propane. The amplitude and phase of the simulated seasonal cycle also agree well with this new observational data set. As shown in Fig. 4, the seasonal cycle is well reproduced at the NH background sites (ALT and BRW). Moreover, Fig. 5 shows that not only the seasonal cycle is correctly reproduced, but also the latitudinal gradient. Generally, the model simulations agree well with the observations in the $\mathrm{NH}$ (where most of the emissions are located). However, at some locations (for example MHD, Mace Head, Ireland and LEF, Park Falls, USA) the model slightly overestimates the observed mixing ratios of propane. In addition, in the SH the simulated mixing ratios seem to be somewhat higher than the observations, especially during the SH winter (June, July and August) in remote regions, and during summer (January and February) in the SH extratropics. Clearly, these findings do not support a further increase of the emissions compared to the data used here.

\section{$4.3 n$-butane, $n-\mathrm{C}_{4} \mathrm{H}_{10}$}

As mentioned in Sect. 4, E1 and E2 reproduce the observed phase of the seasonal cycle of $n$-butane (Fig. 6 and Fig. 7). As observed by Blake et al. (2003) during the TOPSE campaign and also shown by the model, $n$-butane is removed quite rapidly at the onset of summer in all regions, and it is reduced to low levels (almost depleted (single digit $\mathrm{pmol} / \mathrm{mol}$ levels) by late spring, except at the highest latitudes. Examples are (Fig. 7) ALT and BRW, where the simulated mixing ratios (both in simulation E1 and E2) decrease from $\sim 300-400 \mathrm{pmol} / \mathrm{mol}$ in April to $\sim 1-2 \mathrm{pmol} / \mathrm{mol}$ in June and remain at this level during the NH summer (July and August). The ability of the model to reproduce the observed seasonal cycle is also confirmed in Fig. 6, where a high correlation is found between the simulations and the observations for stations located between $40^{\circ} \mathrm{N}$ and $90^{\circ} \mathrm{N}$. In general, simulation E1 (based on anthropogenic emissions taken from the EDGAv2.0 database) produces higher mixing ratios at almost all locations in the $\mathrm{NH}$ compared to simulation E2, as shown in Fig. 6, where the normalised standard deviations of model results from simulation E1 present values larger than 1. The opposite is the case in the $\mathrm{SH}$, with lower mixing ratios in E1 than in E2. Simulation E1 seems to systematically overestimate the winter maximum in the $\mathrm{NH}$ (see Fig. 7, ALT and CBA, Cold Bay, USA, and many others) while simulation E2 is closer to the observed mixing ratios.
Overall, for many stations, simulation E2 better represents the observed mixing ratios than E1 (see Fig. 6). Although a reasonable agreement of simulation E2 with the observations is achieved at Midway Island (MID), and Cape $\mathrm{Ku}-$ mukahi (KUM), two typical marine boundary layer (MBL) background stations, the model underestimates the observed mixing ratios in the $\mathrm{NH}$ summer at these locations. This indicates that a nearby source of $n$-butane may be present, hence that oceanic emissions potentially play a significant role. In the SH, both model simulations seem to underestimate $n$-butane mixing ratios, with almost a total depletion during SH summer at remote locations, which is not observed in the flask data. While both model setups simulate values below $1 \mathrm{pmol} / \mathrm{mol}(\sim 0.5-0.6 \mathrm{pmol} / \mathrm{mol})$ during SH summer (December, January and February), the observations indicate $\sim 10 \mathrm{pmol} / \mathrm{mol}$. This difference suggests localized $n$-butane emissions from the ocean. Additional high precision measurements of this tracer are needed to assess the role of the ocean in these remote areas.

\section{$4.4 i$-butane, $\mathrm{i}-\mathrm{C}_{4} \mathrm{H}_{10}$}

A different picture arises for $i$-butane, for which it is difficult to clearly establish which simulation reproduces the observed mixing ratios better, due to the different performance of the model simulations at different locations. Generally (Fig. 8), the simulated mixing ratios from E1 are at the high end of the observed range for stations in the $\mathrm{NH}$ (normalised standard deviation systematically larger than 1) while the simulated mixing ratios from E2 are at the low end of the observed range for the same locations (normalised standard deviation systematically lower than 1). This can also be clearly seen in the time plot series in Fig. 9 (see, for example, ALT, and CBA). As for $n$-butane, in the SH both model simulations underestimate the observed mixing ratios (see Fig. 9, HBA). Please note that these measurements are close to the NMHC instrumental detection limit, causing an increase of the analytical uncertainty in these data. Simulation E1 does not underestimate $i$-butane in the USA and Europe, in contrast to the results obtained by Jacob et al. (2002). On the contrary, for the USA stations (see Fig. 9, LEF), E1 shows a slight overestimation or (see Fig. 9, UTA) a good agreement with the observations, whereas simulation E2 is too high. For Europe, both simulations E1 and E2 overestimate the observed mixing ratios (see Fig. 9, Ochsenkopf station, OXK, Germany), where the discrepancy is largest for E2. It must be stressed that both simulations predict a large variability at Ochsenkopf station. The coarse grid resolution hence prevents us from deciding which emission database is best in reproducing European or USA emissions. It is actually expected that simulation E2 reproduces observations in the USA better than simulation E1, because the Bey et al. (2001) emissions database was calculated based on USA data (see Wang et al., 1998). However, this is not always the case; in particular, at Park Falls (LEF), simulation E2 is better than 

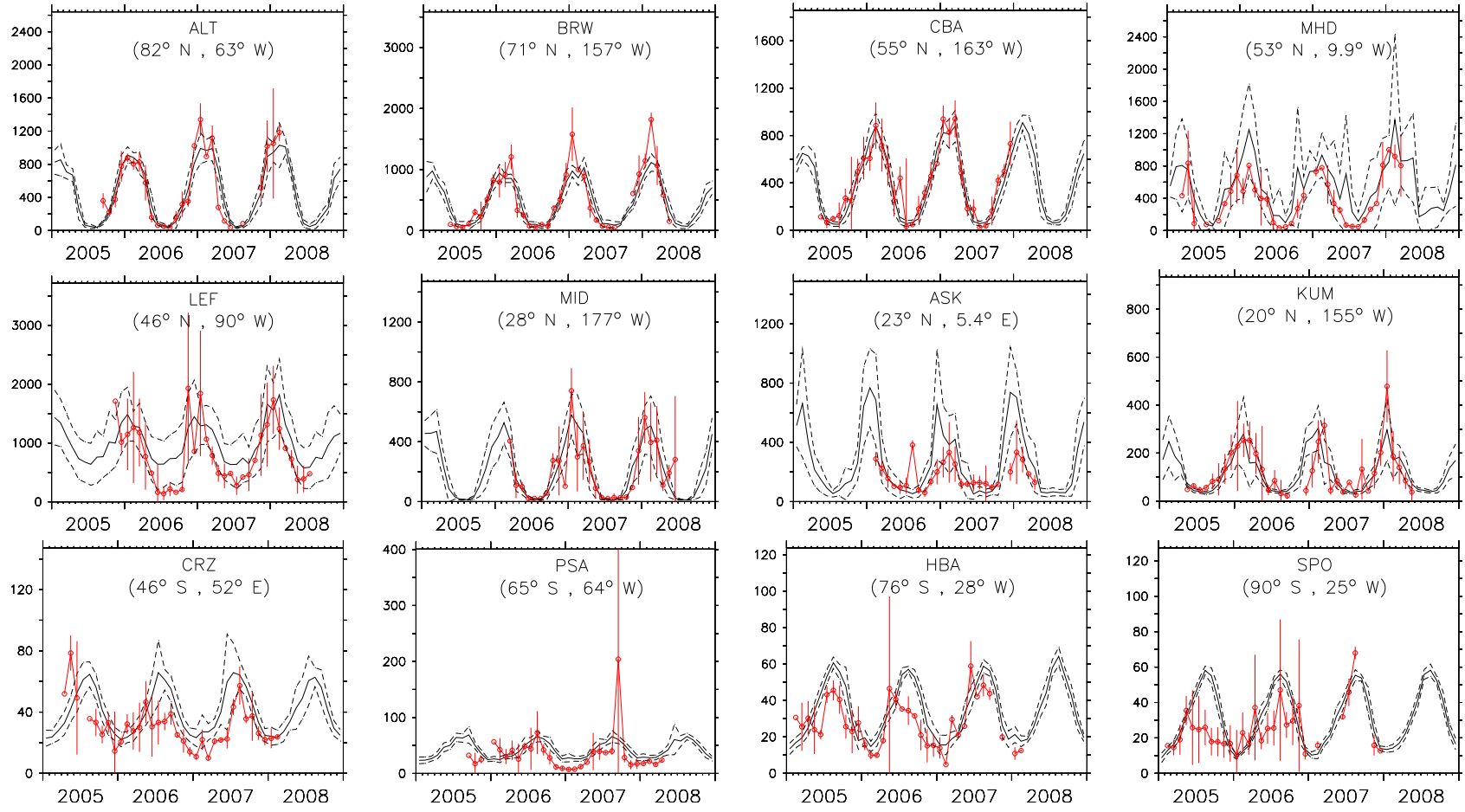

Fig. 4. As Fig. 2 for $\mathrm{C}_{3} \mathrm{H}_{8}$.

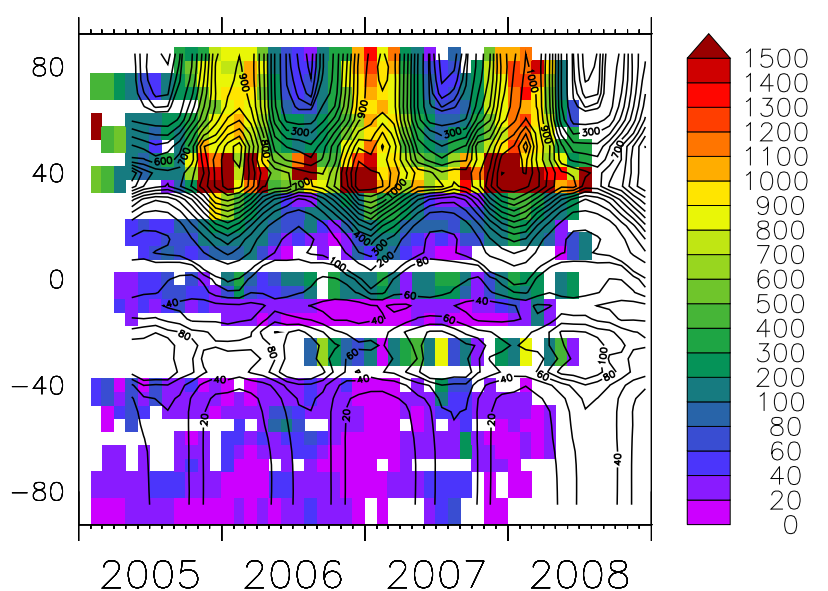

Fig. 5. Seasonal cycle and latitudinal distribution of propane $\left(\mathrm{C}_{3} \mathrm{H}_{8}\right)$. The colour code denotes the mixing ratios in $\mathrm{pmol} / \mathrm{mol}$, calculated as a zonal average of the measurements available in the NOAA/ESRL GMD dataset. The superimposed contour lines denote the zonal averages of the model results.

simulation E1. In contrast, at Wendower (UTA) simulation $\mathrm{E} 1$ is better than E2. For the SH, due to the low mixing ratios of $i$-butane (close to instrumental detection limit) and the high variability of the observations, it is difficult to draw a firm conclusion. However, at Halley Bay Station (HBA,
Antarctica) simulation E2 reproduces the first year of observations (2005) better than E1.

\section{$4.5 \quad n$-pentane, $\mathrm{n}-\mathrm{C}_{5} \mathrm{H}_{12}$}

As for $i$-butane, also for this tracer it is difficult to establish clearly which simulation better represents the observations, as both agree well with the observed values at the remote locations in the $\mathrm{NH}$. The comparison between simulation results and observations (Fig. 10) shows a poor agreement at stations located in the tropics and in the $\mathrm{SH}$. In the $\mathrm{NH}$, at locations north of $60^{\circ} \mathrm{N}$, the centered pattern root mean square (RMS) difference is similar for both simulations, whereas at locations between 20 and $30^{\circ} \mathrm{N}$ simulation $\mathrm{E} 1$ is slightly better than simulation E2. This can also be seen (see Fig. 11) at BRW, where simulation E1 reproduces very well the observed mixing ratios, while in contrast at Storhofdi, Iceland (ICE), the results from simulation E2 are in better agreement with the measurements. The simulated mixing ratios are lower than observed throughout all seasons in the tropics and in the SH (Fig. 11, BKT, Bukit Kototabang, Indonesia, and HBA, Antarctica) in both simulations E1 and E2. However, as mentioned earlier, in $\mathrm{SH}$ remote regions the mixing ratios are close to the instrumental detection limits and the instrumental error is relatively large. Nevertheless, a bias between the model results and the observations is evident; the short lifetime of $\mathrm{n}^{-} \mathrm{C}_{5} \mathrm{H}_{12}$ (shorter than the interhemispheric exchange time), indicates that the emissions are generally 


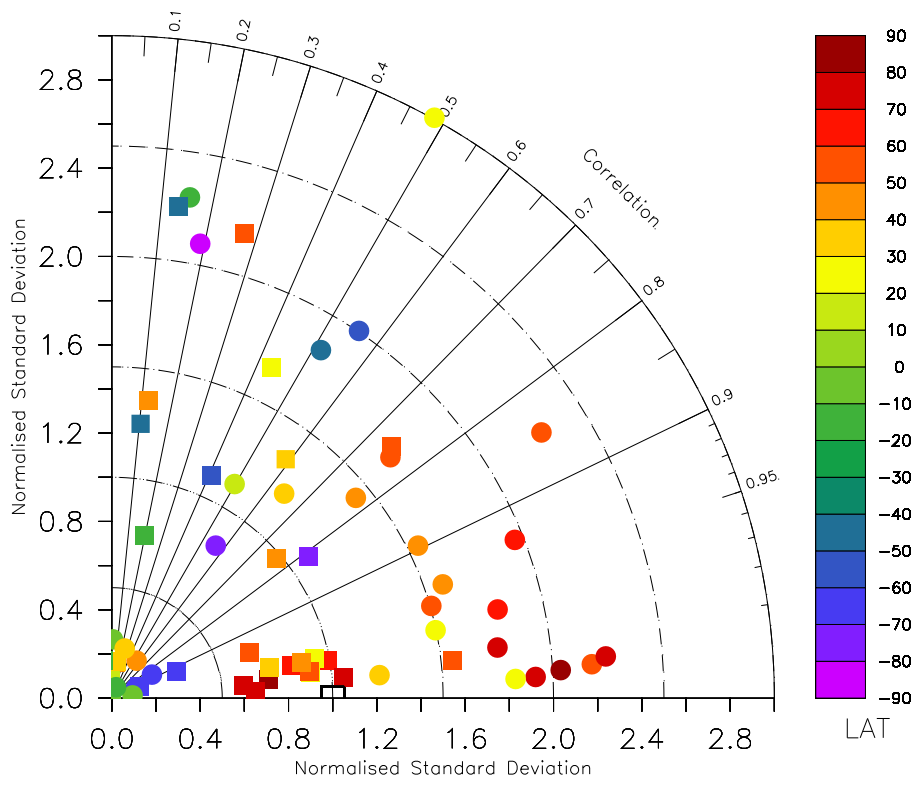

Fig. 6. Taylor diagram comparing monthly averages of $n-\mathrm{C}_{4} \mathrm{H}_{10}$ from the model simulations with the surface observations from the NOAA ESRL GMD network. The colour code denotes the geographic latitude. The symbol denote the model results: circle from simulation E1, square from simulation E2.
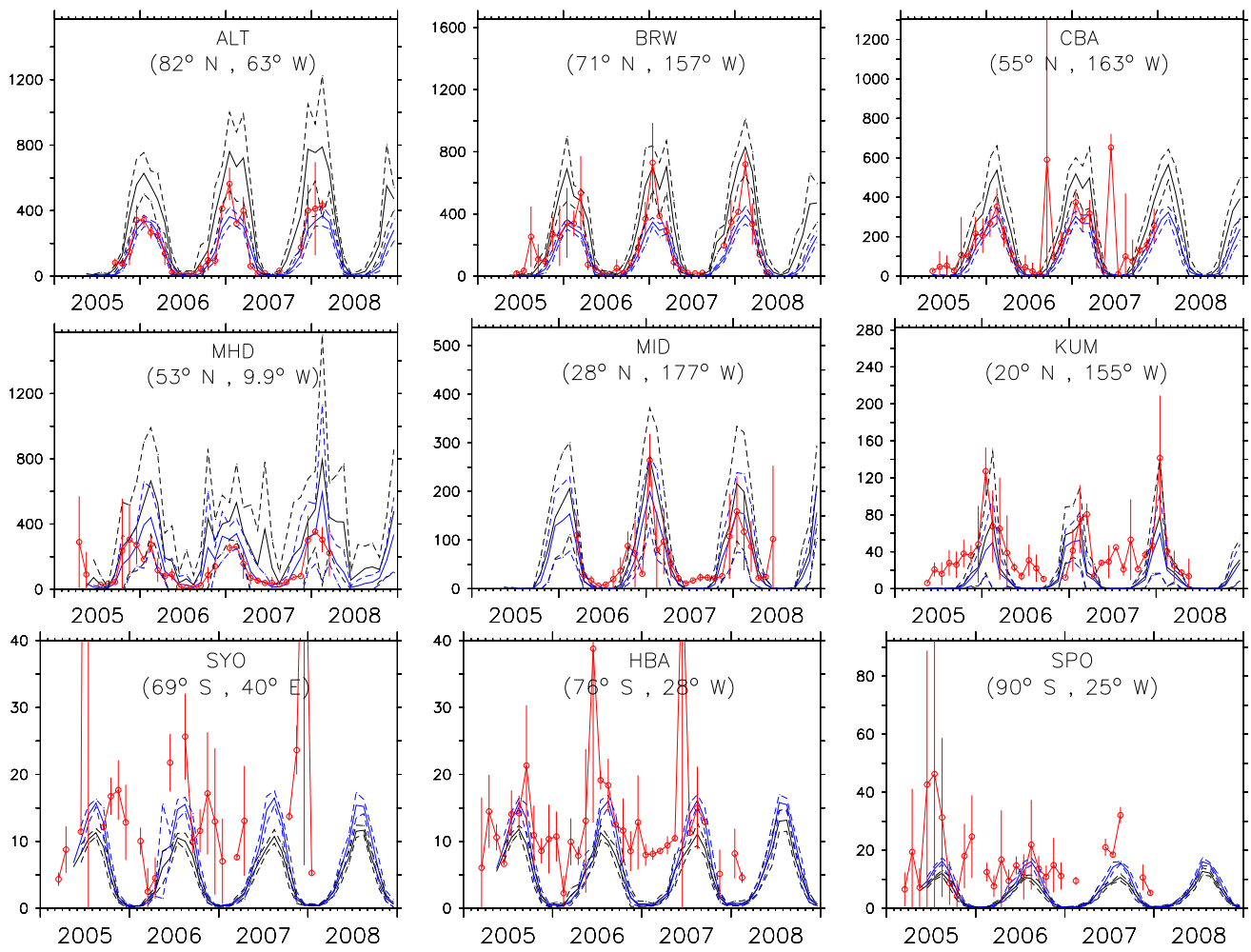

Fig. 7. Comparison of simulated and observed $\mathrm{n}-\mathrm{C}_{4} \mathrm{H}_{10}$ mixing ratios in pmol/mol for some selected locations (ordered by latitude). The red line and the bars represent the monthly average and the variability (calculated as the monthly standard deviations) of the measurements. The simulated monthly average is indicated in the solid line and the corresponding simulated monthly variability (calculated as the monthly standard deviations of the simulated mixing ratios) by the dashed line. The black and blue colours denote results from simulation E1 and E2, respectively. The three letters at the center of each plot denote the station code (see http://www.esrl.noaa.gov/gmd/ccgg/flask.html). Note the different scales of the vertical mixing ratio axes. 


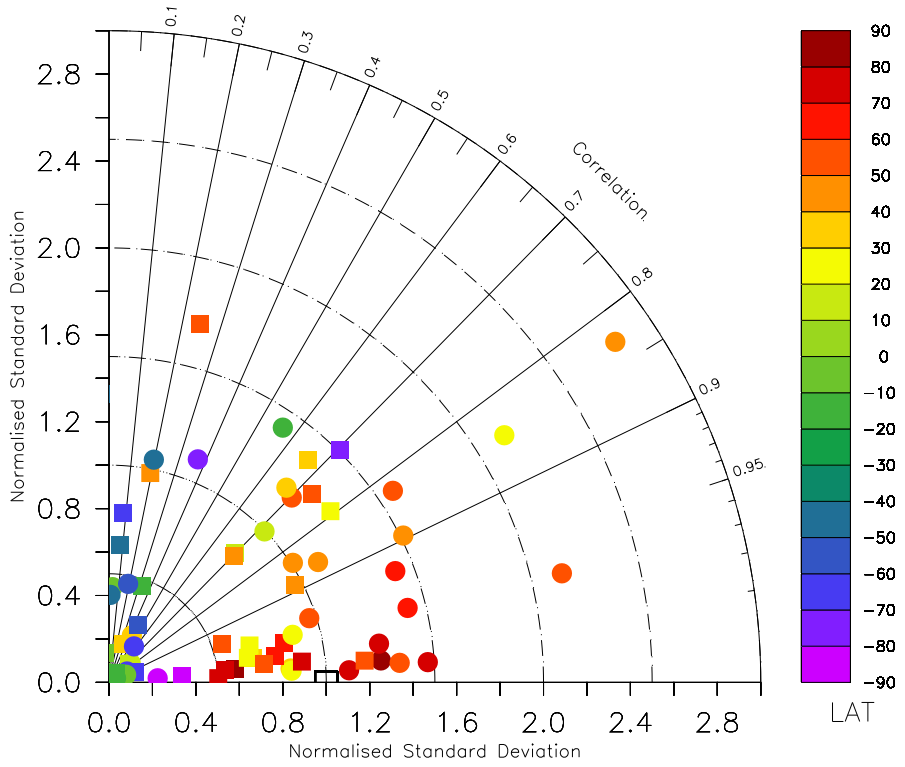

Fig. 8. As Fig. 6 for i- $\mathrm{C}_{4} \mathrm{H}_{10}$.
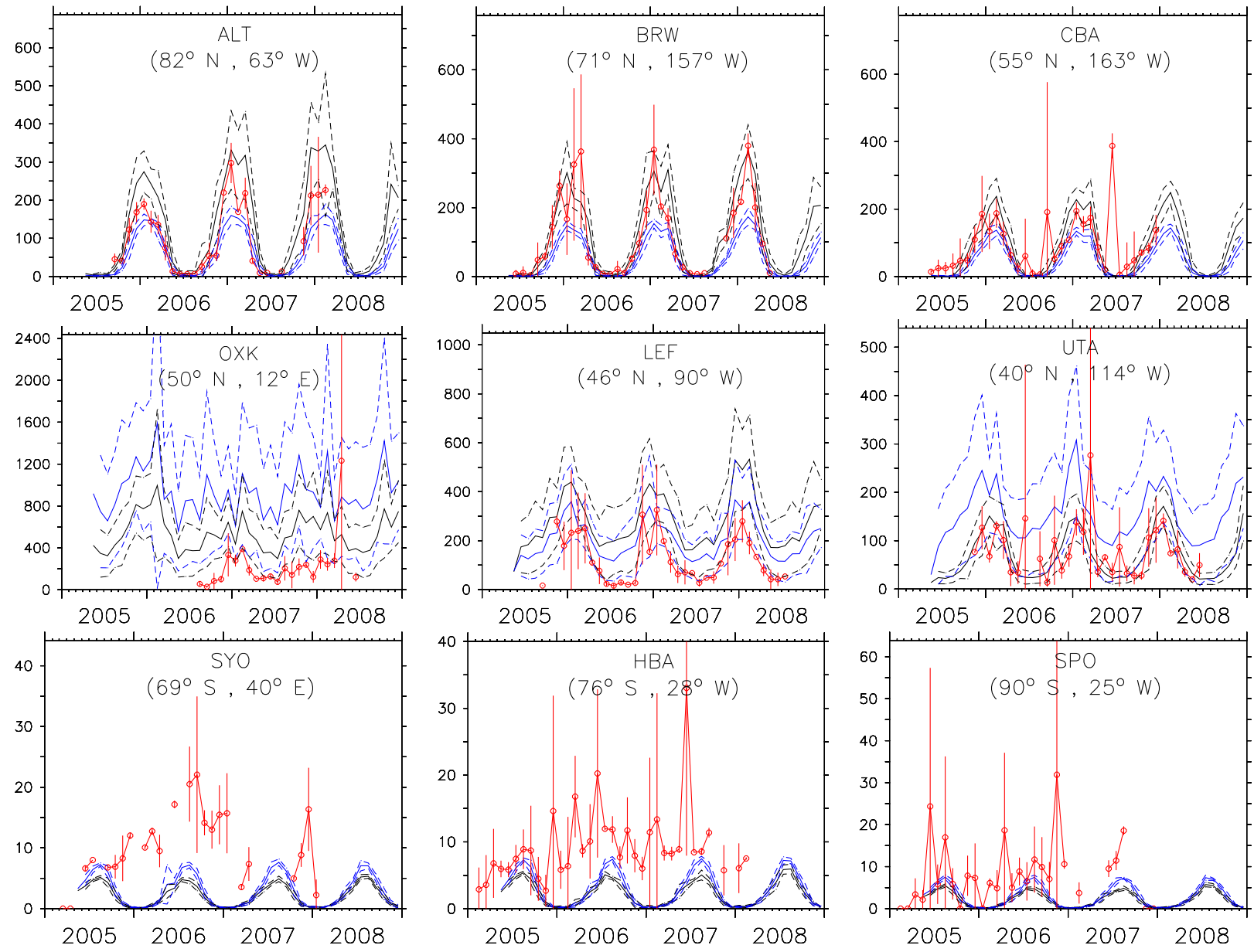

Fig. 9. As Fig. 7 for i- $\mathrm{C}_{4} \mathrm{H}_{10}$. 


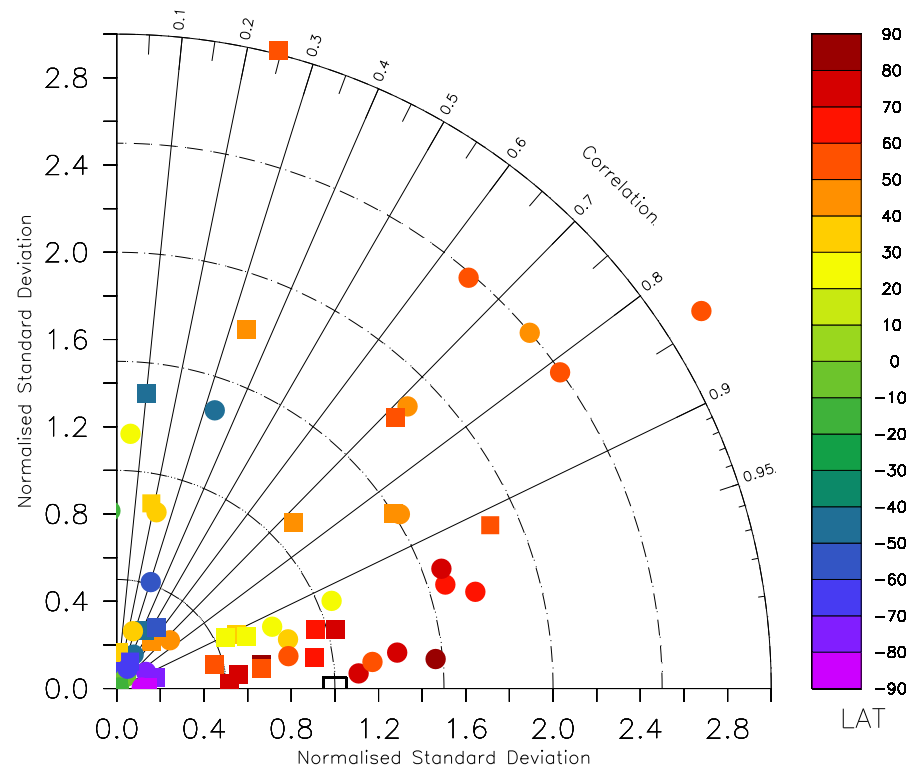

Fig. 10. As Fig. 6 for $n-\mathrm{C}_{5} \mathrm{H}_{12}$.
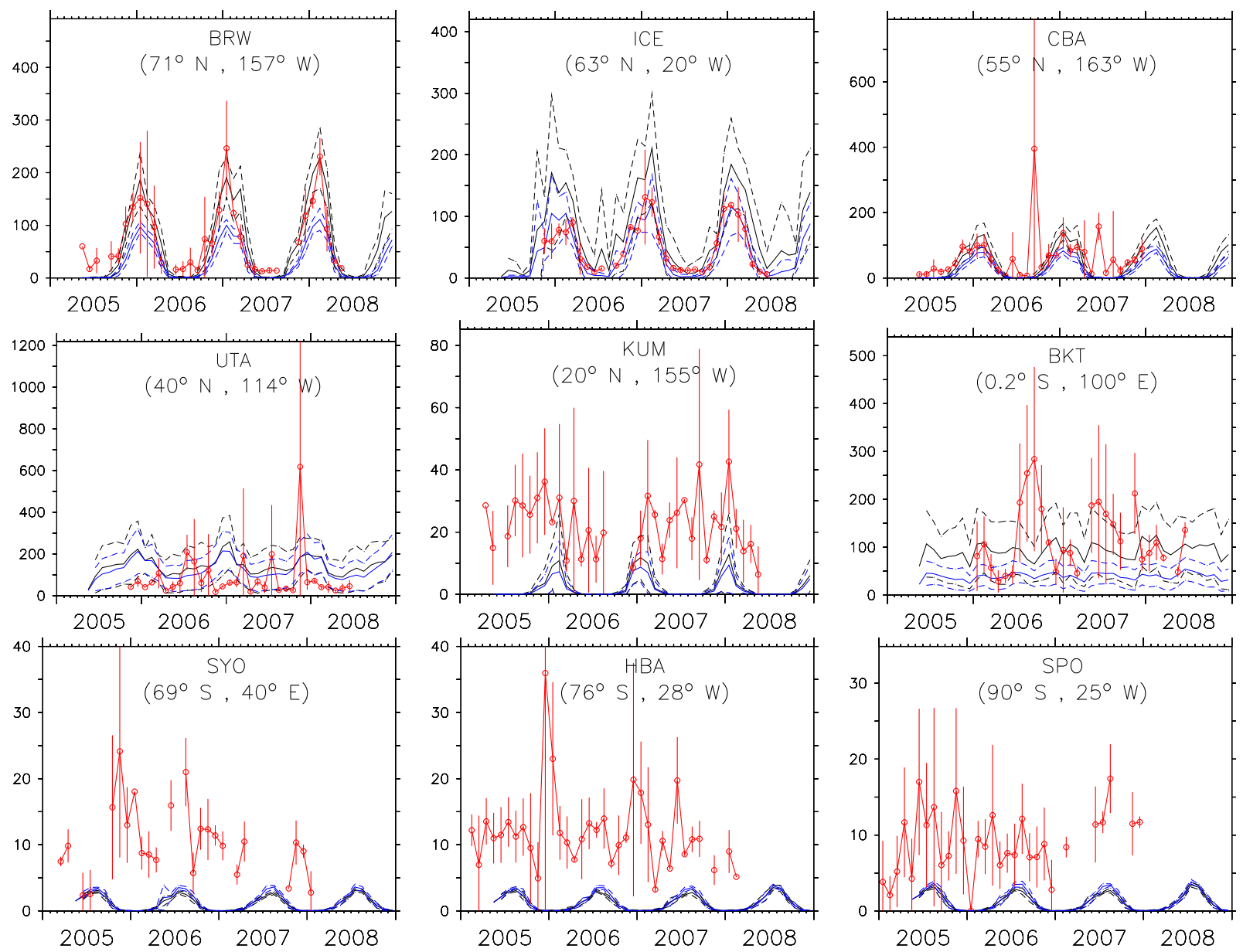

Fig. 11. As Fig. 7 for $n-C_{5} \mathrm{H}_{12}$. 
underestimated in the $\mathrm{SH}$. This is corroborated by similar results for $i$-pentane (see also Sect. 4.6).

\section{$4.6 i$-pentane, $\mathrm{i}-\mathrm{C}_{5} \mathrm{H}_{12}$}

In contrast to $n$-pentane, north of $60^{\circ} \mathrm{N}$, the mixing ratios from simulation E2 present a better agreement (i.e. lower centered pattern RMS difference) with the observations than simulation E1 (see Fig. 12). At these latitudes, the amplitude of the seasonal cycle is overestimated by at least $60 \%$ in simulation E1 (visible from the normalised standard deviations), whereas it is within $40 \%$ in simulation E2. The overestimation of the simulated mixing ratios from simulation $\mathrm{E} 1$ with respect to the observations in the $\mathrm{NH}$ remote regions can be also seen in the time series plots (see Fig. 13, ALT), where it is highest during the $\mathrm{NH}$ winter, with a difference of a factor of 2. On the other hand, the model (both simulation $\mathrm{E} 1$ and $\mathrm{E} 2$ ) tends to underestimate the mixing ratios of $\mathrm{i}-\mathrm{C}_{5} \mathrm{H}_{12}$ in the $\mathrm{NH}$ subtropics and in the $\mathrm{SH}$ (see Fig. 13, MID and KUM). This systematic underestimation of the observed mixing ratios for the SH stations is again confirmed in Fig. 13. As mentioned in Sect. 4.5, this points to a partially wrong distribution of the emissions in the model, which are located almost exclusively in the NH, notably in the industrialised regions.

\subsection{Global $\mathrm{C}_{2}-\mathrm{C}_{5}$ alkanes budgets}

Following the analyses performed in Sects. 4.1-4.6, a global inventory of $\mathrm{C}_{2}-\mathrm{C}_{5}$ alkane emissions is shown in Table 2. Anthropogenic emissions are the most important sources in the budget of these tracers, ranging from $\sim 75 \%$ (for ethane) to $\sim 98 \%$ (for butanes and pentanes) of the total emissions. For butanes and pentanes, the dataset presented by Bey et al. (2001) (with an increased total emissions for pentanes) gives the best results with the EMAC model, and is recommended for future studies of these tracers. For ethane and propane, the model simulation with the EDGARv3.2 fasttrack database gives satisfactory results.

Biomass burning is the second important source for ethane and propane, i.e. $\sim 22 \%$ and $\sim 7 \%$ of the total sources, respectively. As shown by Helmig et al. (2008), biomass burning effects on $\mathrm{C}_{3}-\mathrm{C}_{5}$ alkanes is generally sporadic. Hence, the monthly average values of the observational dataset used here generally masked the biomass burning signal that could be observed. In addition the coarse model resolution and the low estimated value limit the possibilities to further evaluate this type of emission. These values could hence not be confirmed by our study and are reported as suggested in the literature.

Oceanic emissions play a small role in the budget for ethane and propane. The theoretical magnitude of oceanic emission for $\mathrm{C}_{4}-\mathrm{C}_{5}$ is comparable to the one of biomass burning, and hence too weak to be clearly distinguished in the observational dataset. Nevertheless, our analysis suggests that oceanic emissions can play a more significant role also for butanes and pentanes, at least at some coastal locations.

\section{Contributions to the atmospheric budget of some OVOC}

\subsection{Acetone formation}

Acetone $\left(\mathrm{CH}_{3} \mathrm{COCH}_{3}\right)$, due to its photolysis, plays an important role in the upper tropospheric $\mathrm{HO}_{\mathrm{x}}$ budget (Singh et al., 1995; McKeen et al., 1997; Müller and Brasseur, 1995; Wennberg et al., 1998; Jaeglé et al., 2001) although recent studies have considerably reduced it (Blitz et al., 2004). Moreover, this trace gas is essential to correctly describe the ozone enhancement in flight corridors (Brühl et al., 2000; Folkins and Chatfield, 2000). Oxidation of propane and $\mathrm{C}_{4}$ $\mathrm{C}_{5}$ isoalkanes (Singh et al., 1994) has been estimated to be $\sim 20-30 \%$ of the total sources of acetone (Jacob et al., 2002; Singh et al., 2004). It must be however stressed that there is still no agreement on the acetone budget. Recent studies, in fact, have modified significantly the estimated sources/sinks. Following recent studies, it is now widely thought that acetone has a net sink in the ocean (Singh et al. (2004), Marandino et al. (2005), and Taddei et al. (2009)). The lack of emissions from the ocean in the budget, however, is partially compensated by two other terms in the acetone budget:

- reduced photolysis, following the studies of Blitz et al. (2004) and Arnold et al. (2005).

- increased biogenic emissions. As pointed out by Singh et al. (2004, see also references therein), new measurements suggest higher biogenic emissions than the one proposed by Jacob et al. (2002) (33 Tg/yr). Based on the modeling study of Potter et al. (2003), the biogenic emissions should be in the range of 50-170 Tg/yr.

The transport and chemical production of acetone were explicitly calculated with EMAC. Since E2 better reproduces the observations, we used the results of this simulation to quantify the acetone production. Globally, the total production of acetone from $\mathrm{C}_{3}-\mathrm{C}_{5}$ alkanes is $21.3 \mathrm{Tg} / \mathrm{yr}$ in E2. The propane decomposition, with a yield of 0.73 , produces $\sim 11.2 \mathrm{Tg} / \mathrm{yr}$ of acetone, which is higher than the total production of acetone from $\mathrm{C}_{4}-\mathrm{C}_{5}$ isoalkanes oxidation, namely $10.1 \mathrm{Tg} / \mathrm{yr}$. In fact, $i$-butane oxidation produces 4.3 $\mathrm{Tg} / \mathrm{yr}$ acetone, while $5.8 \mathrm{Tg} / \mathrm{yr}$ of acetone are produced by $i$-pentane oxidation. This is the same for both simulations, because total emissions are equal. Despite the fact that both simulations produce very similar amounts of acetone, the production is distributed quite differently in the two simulations.

As shown in Fig. 14, simulation E1 indicates a pronounced acetone production over the middle East and Persian Gulf, northern Europe and western USA, compared to simulation 


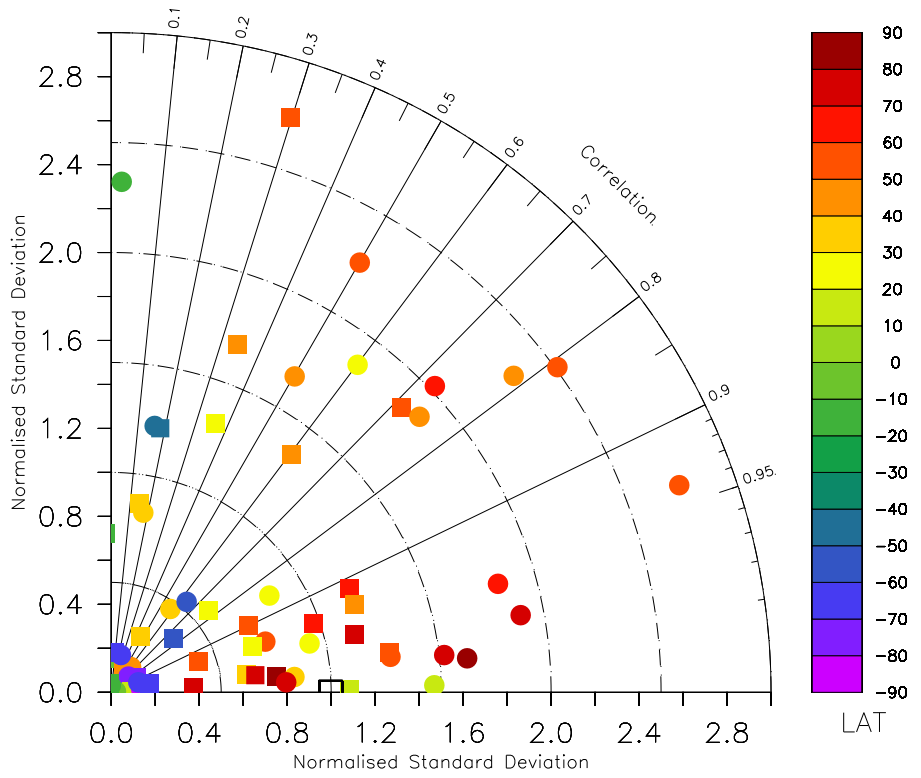

Fig. 12. As Fig. 6 for i- $\mathrm{C}_{5} \mathrm{H}_{12}$.
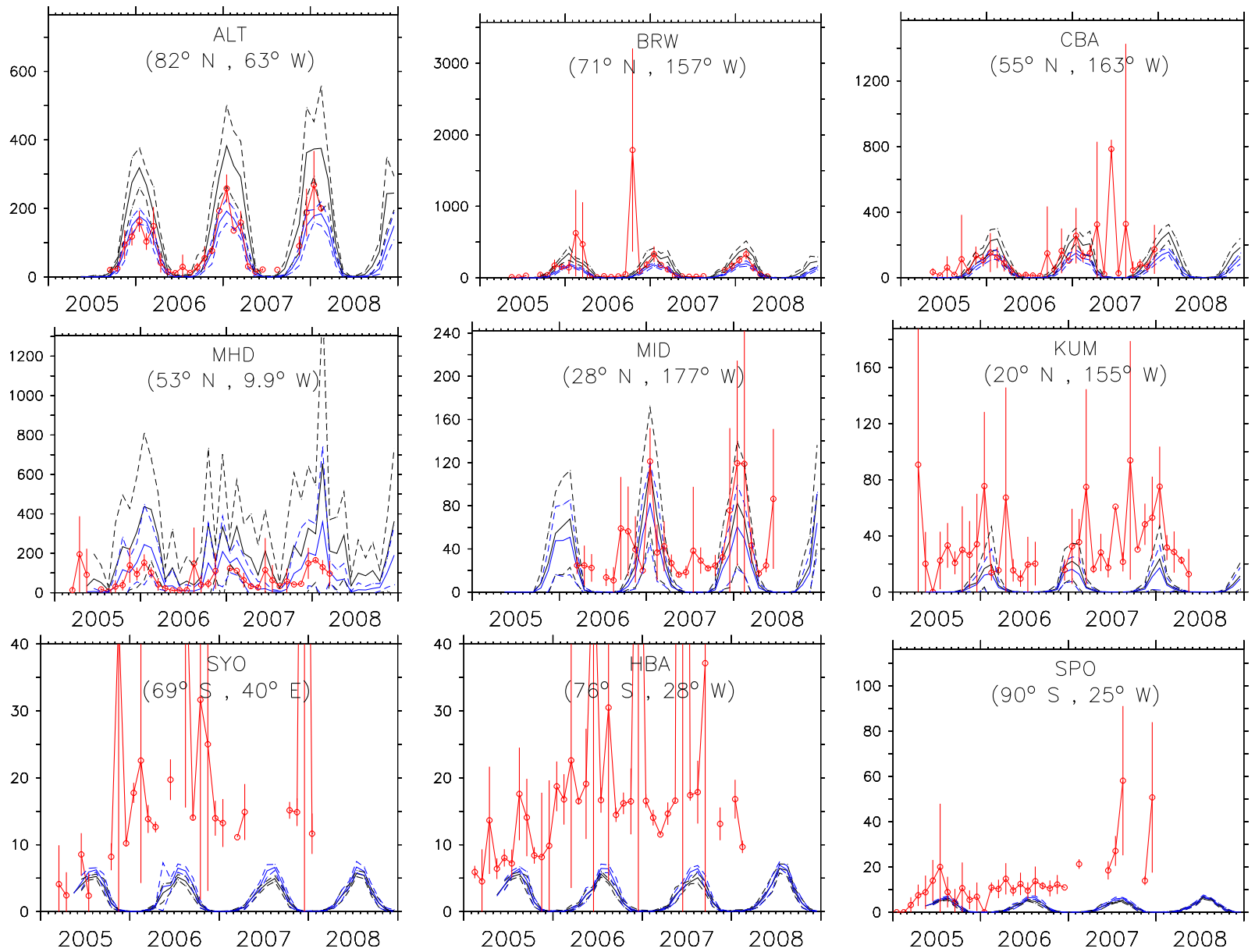

Fig. 13. As Fig. 7 for i- $\mathrm{C}_{5} \mathrm{H}_{12}$. 
Table 2. Global source estimates of $\mathrm{C}_{2}-\mathrm{C}_{5}$ alkanes based on the present EMAC simulations (in $\mathrm{Tg}$ (species)/yr).

\begin{tabular}{lcccccc}
\hline & $\mathrm{C}_{2} \mathrm{H}_{6}$ & $\mathrm{C}_{3} \mathrm{H}_{8}$ & ${ }^{n}-\mathrm{C}_{4} \mathrm{H}_{10}$ & $\mathrm{i}-\mathrm{C}_{4} \mathrm{H}_{10}$ & ${ }^{\mathrm{n}-\mathrm{C}_{5} \mathrm{H}_{12}}$ & $\mathrm{i}-\mathrm{C}_{5} \mathrm{H}_{12}$ \\
\hline anthropogenic & $9.2^{\mathrm{b}}$ & $10.5^{\mathrm{b}}$ & $10.15^{\mathrm{a}}$ & $4.35^{\mathrm{a}}$ & $4.3^{\mathrm{a}}$ & $8.0^{\mathrm{a}}$ \\
biomass burning & $2.8^{\mathrm{d}}$ & $0.9^{\mathrm{d}}$ & $0.2^{\mathrm{d}}$ & $0.07^{\mathrm{d}}$ & $0.1^{\mathrm{d}}$ & $0.08^{\mathrm{d}}$ \\
oceanic & $0.5^{\mathrm{c}}$ & $0.3^{\mathrm{c}}$ & - & - & - & - \\
total & 12.5 & 11.7 & 10.3 & 4.4 & 4.4 & 8.1 \\
\hline
\end{tabular}

a simulation E2, with emissions distribution from Bey et al. (2001);

b based on EDGARv3.2, fast-track 2000;

c based on Plass-Dülmer et al. (1995);

$\mathrm{d}$ estimates based on Van der Werf et al. (2004) and Andreae and Merlet (2001) for the year 2000 (see Sect. 2.2.2).

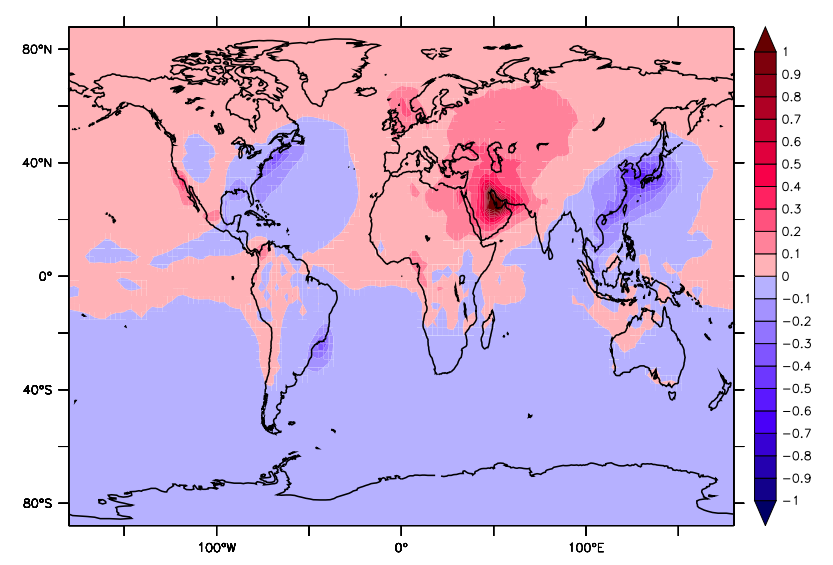

Fig. 14. Difference between the simulated annual average surface mixing ratios of $\mathrm{CH}_{3} \mathrm{COCH}_{3}$ from simulation $\mathrm{E} 1$ and the simulation $\mathrm{E} 2$, in $\mathrm{nmol} / \mathrm{mol}(\mathrm{E} 1-\mathrm{E} 2)$.

E2. On the other hand, simulation E2 indicates a stronger production of acetone in the eastern USA, China, and in the $\mathrm{SH}$. In both model simulations, $\mathrm{CH}_{3} \mathrm{COCH}_{3}$ is produced almost solely by the reaction of the iso-alkanes with $\mathrm{OH}$; the contributions of the reactions with $\mathrm{Cl}$ and $\mathrm{NO}_{3}$ are negligible, being less than $0.5 \%$ of the total. Our result partially confirms the conclusion of Jacob et al. (2002), who calculated an acetone production of $14 \mathrm{Tg} / \mathrm{yr}, 4.0 \mathrm{Tg} / \mathrm{yr}$ and $2.6 \mathrm{Tg} / \mathrm{yr}$ from propane, $i$-butane and $i$-pentane, respectively. The different acetone production compared to the study of Jacob et al. (2002) (present for propane and $i$-pentane decomposition) arise from the different emissions and/or the acetone yield. For instance, Jacob et al. (2002) used an acetone yield of 0.53 from $i$-pentane (from the reaction with $\mathrm{OH}$ ). In our study an acetone yield of $\sim 0.90$ from $i$-pentane was obtained. In addition the $i$-pentane emissions are substantially different, being 6.0 and $8.0 \mathrm{Tg} / \mathrm{yr}$ in the study of Jacob et al. (2002), and our study, respectively. For propane, the acetone yield is very similar $(0.72)$ to the one obtained here (0.73), but a difference in the emissions ( 13.5 vs. $11.7 \mathrm{Tg} / \mathrm{yr})$ causes a slight difference in the acetone production. Because the E2 results reproduce $i$-butane and $i$-pentane better, we use this model simulation for the comparison with the evaluation simulation $\mathrm{S} 1$ (see Sect. 2). The $\mathrm{S} 1$ analysis did not account for $\mathrm{C}_{4}-\mathrm{C}_{5}$ alkanes and their subsequent atmospheric reactions. This allows us to evaluate the effect of higher alkanes on acetone.

The resulting increase of the acetone mixing ratios is evident, especially in the NH. As shown in Fig. 15, the acetone mixing ratio increased at the surface between 100 and $300 \mathrm{pmol} / \mathrm{mol}$ in $\mathrm{NH}$ remote areas, with the highest values reached in locations downwind of polluted regions (for example over the Pacific and Atlantic Ocean). The relative effect in polluted regions is smaller (maximum increase $\sim 30 \%$ ) due to the strong anthropogenic emission of acetone. However, the contributions from the alkanes oxidation are significant (up to $1 \mathrm{nmol} / \mathrm{mol}$ ). The strongest production regions are located over polluted regions such as the eastern USA, the Mediterranean area and the China-Japan region. Here the maximum effect of $\mathrm{C}_{4}-\mathrm{C}_{5}$ alkanes on acetone is achieved, with an increase of $\sim 1 \mathrm{nmol} / \mathrm{mol}$. The mixing ratio of acetone in the SH is practically not affected by chemical formation from iso-alkanes, with the exception of a few locations in South America, simply because they are mainly emitted in the NH. This, combined with their short lifetime (shorter than the interhemispheric exchange time), confine the iso-alkanes to decompose and produce acetone only in the $\mathrm{NH}$.

To confirm the improvements in the acetone budget obtained by including the $\mathrm{C}_{4}-\mathrm{C}_{5}$ alkanes, the model simulation was compared with field data reported by Emmons et al. (2000). In Fig. 16, we show only campaigns performed in the $\mathrm{NH}$ where the differences between simulations E2 and S1 are largest. We refer to Pozzer et al. (2007) and the electronic supplement for the complete comparison (see http://www.atmos-chem-phys.net/10/4403/ 2010/acp-10-4403-2010-supplement.pdf). The inclusion of the $\mathrm{C}_{4}-\mathrm{C}_{5}$ alkanes chemistry substantially increases the mixing ratios of acetone in the North Pacific region (PEMTropics-B and PEM-West-B). In these cases, the increase 


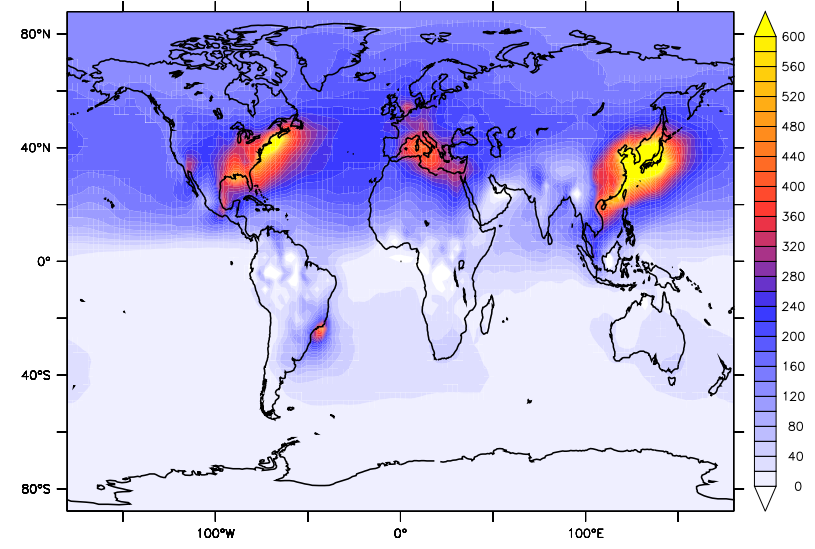

Fig. 15. Difference between the simulated annual average surface mixing ratios of $\mathrm{CH}_{3} \mathrm{COCH}_{3}$ from simulation $\mathrm{E} 2$ and the evaluation simulation $\mathrm{S} 1$, in $\mathrm{pmol} / \mathrm{mol}(\mathrm{E} 2-\mathrm{S} 1)$.

is $\sim 50 \%$ compared to a simulation without $\mathrm{C}_{4}-\mathrm{C}_{5}$ alkanes. The simulated mixing ratios thus agree much better with the measurements. Especially below $5 \mathrm{~km}$ altitude, the simulated vertical profiles are closer to the observations, and improved compared to simulation S1. In a polluted region (TRACE-P, Fig. 16) downwind of China, the inclusion of $\mathrm{C}_{4}-\mathrm{C}_{5}$ compounds results in a remarkable improvement of the acetone simulation. The underestimation of the freetroposphere mixing ratios seems to support the revision of the acetone quantum yield, as proposed by Blitz et al. (2004). Arnold et al. (2005), in fact, calculated an average increase of $\sim 60-80 \%$ of acetone in the upper troposphere. It must be stressed, however, that in two cases the comparison between the model results from simulation E2 and field campaigns deteriorates compared to the evaluation simulation S1. These are presented in Fig. 16 (bottom). Both cases are located in Japan, where the model, after the inclusion of $\mathrm{C}_{4}-\mathrm{C}_{5}$ oxidation pathways in the chemistry scheme, simulates mixing ratios that are higher than the observations. This could be due to a too strong source of $\mathrm{C}_{4}-\mathrm{C}_{5}$ alkanes in the region in simulation $\mathrm{E} 2$, or alternatively, an overestimation/underestimation of direct acetone emissions/depositions.

\subsection{Acetaldehyde formation}

Acetaldehyde $\left(\mathrm{CH}_{3} \mathrm{CHO}\right)$ is also formed during the chemical degradation of $\mathrm{C}_{3}-\mathrm{C}_{5}$ alkanes. This tracer is a shortlived compound, with an average lifetime of several hours (Tyndall et al., 1995, 2002). It is an important precursor of PAN (peroxyacetyl nitrate), being a reservoir species of $\mathrm{NO}_{\mathrm{x}}$ (see Singh et al., 1985; Moxim et al., 1996). Oxidation of alkanes is responsible for $\sim 15-19 \%$ of the total acetaldehyde emissions (Singh et al., 2004), or $\sim 20-27 \%$ based on a more recent estimate (Millet et al., 2010). In this study, using the EMAC model, the calculated global production
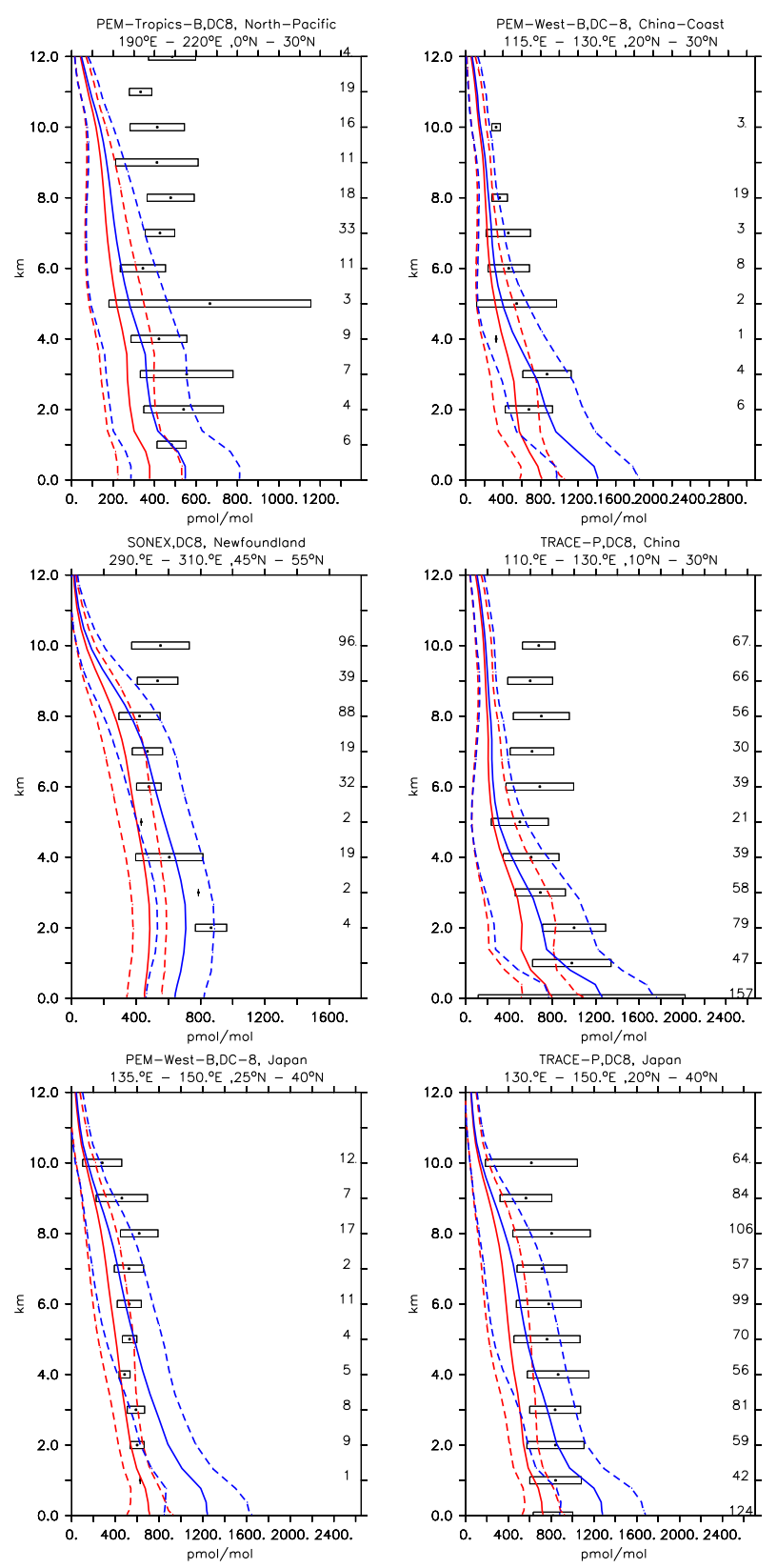

Fig. 16. Vertical profiles of $\mathrm{CH}_{3} \mathrm{COCH}_{3}$ (in pmol/mol) for some selected campaigns from Emmons et al. (2000). Asterisks and boxes represent the average and the variability (with respect to space and time) of the measurements in the region, respectively. The simulated average is indicated by the solid line and the corresponding simulated variability (calculated as standard deviation with respect to time and space) by the dashed lines. The numbers of measurements are listed near the right axes. The red lines represent the simulation S1, the blue lines E2. The PEM-Tropics-B, PEMWest-B, SONEX and TRACE-P campaign took place in MarchApril (1999), February-March (1994), October-November (1997) and February-April (2001), respectively. 
of acetaldehyde from $\mathrm{C}_{2}-\mathrm{C}_{5}$ alkanes is $30.8 \mathrm{Tg} / \mathrm{yr}$. In both simulations $\mathrm{E} 1$ and $\mathrm{E} 2,18.1 \mathrm{Tg} / \mathrm{yr}$ and $3.1 \mathrm{Tg} / \mathrm{yr}$ of acetaldehyde are formed by the oxidation of ethane $\left(\mathrm{C}_{2} \mathrm{H}_{6}\right)$ and propane $\left(\mathrm{C}_{3} \mathrm{H}_{8}\right)$, respectively. In addition, $3.4 \mathrm{Tg} / \mathrm{yr}$, $1.4 \mathrm{Tg} / \mathrm{yr}$ and $4.8 \mathrm{Tg} / \mathrm{yr}$ of acetaldehyde result from the oxidation of $n$-butane $\left(\mathrm{n}-\mathrm{C}_{4} \mathrm{H}_{10}\right), n$-pentane $\left(\mathrm{n}-\mathrm{C}_{5} \mathrm{H}_{12}\right)$ and $i$ pentane $\left(\mathrm{i}-\mathrm{C}_{5} \mathrm{H}_{12}\right)$, respectively. These amounts are almost exclusively produced by the reaction with $\mathrm{OH}$; in fact, the reaction of $\mathrm{C}_{3}-\mathrm{C}_{5}$ alkanes with $\mathrm{NO}_{3}$ produces only $0.1 \%$ of the total acetaldehyde.

\section{Conclusions}

We compared the EMAC model results of $\mathrm{C}_{2}-\mathrm{C}_{5}$ alkanes with new observational data obtained from flask measurements from the NOAA/ESRL flask sampling network. Two emission distribution databases for butanes and pentanes (and associated isomers) were evaluated, new emissions of $\mathrm{C}_{2}-\mathrm{C}_{5}$ estimated, and the effect of $\mathrm{C}_{3}-\mathrm{C}_{5}$ alkanes on the concentrations of acetone and acetaldehyde calculated.

Overall, the model reproduces the observations of ethane and propane mixing ratios well using the EDGARv3.2 emission database (van Aardenne et al., 2005). The seasonal cycle is correctly reproduced, and the simulated mixing ratios are generally within $20 \%$ of the observations for ethane and propane. The simulation of ethane $\left(\mathrm{C}_{2} \mathrm{H}_{6}\right)$ shows a good agreement with the observations, both with respect to the spatial and the temporal distribution, although with some underestimation in the $\mathrm{NH}$ during winter. In the $\mathrm{SH}$ a general overestimation is found, especially during the $\mathrm{SH}$ summer. Propane $\left(\mathrm{C}_{3} \mathrm{H}_{8}\right)$ is reproduced well in the $\mathrm{NH}$, while in the $\mathrm{SH}$ an overestimation occurs during the $\mathrm{SH}$ winter.

To compare two different emissions databases, two sensitivity simulations were performed. In simulation E1 the EDGARv2 (Olivier et al., 1999) emissions for butanes and pentanes, and in simulation E2 the emission distributions suggested by Bey et al. (2001) were used. Generally, the simulated seasonal cycles of the butanes and pentanes agree well with the observations in both simulations. However, simulation E2 reproduces more realistically both, $n$-butane and $i$-pentane, while for $i$-butane and $n$-pentane it is not evident which simulation is better, one being at the higher end of the observations (E1) and the other at the lower end (E2). In conclusion, we recommend the emission database suggested by Bey et al. (2001) (with additionally increased pentanes emissions) for future studies of these tracers. In addition, our analysis suggests a larger source from the ocean than what is currently assumed. A simulation with higher spatial resolution would give additional information on the global impact of biomass burning on these tracers, which, due to the small emitted amount compared to anthropogenic emissions, is difficult to analyse and quantify with this low resolution model.

The inclusion of $\mathrm{C}_{4}-\mathrm{C}_{5}$ alkanes in the model improves the representation of acetone $\left(\mathrm{CH}_{3} \mathrm{COCH}_{3}\right)$. Based on simulation E2, $i$-butane and $i$-pentane degradation produces $\sim 4.3$ and $\sim 5.8 \mathrm{Tg} / \mathrm{yr}$ of acetone, respectively. At the same time, the formation of acetaldehyde was also calculated, resulting in a production rate of $3.4 \mathrm{Tg} / \mathrm{yr}, 1.4 \mathrm{Tg} / \mathrm{yr}$ and $4.8 \mathrm{Tg} / \mathrm{yr}$ from the oxidation of $n$-butane, $n$-pentane and $i$ pentane, respectively. The role of $\mathrm{NO}_{3}$ and $\mathrm{Cl}$ radicals in the degradation of $\mathrm{C}_{3}-\mathrm{C}_{5}$ isoalkanes and the formation of acetone and acetaldehyde is negligible, contributing less than $1 \%$ to the total chemical production.

Acknowledgements. We would like to thank Tzung-May $\mathrm{Fu}$ for providing the emissions used for simulation E2. We wish also to acknowledge the use of the Ferret program for analysis and graphics in this paper. Ferret is a product of NOAA's Pacific Marine Environmental Laboratory (information is available at http://www.ferret.noaa.gov). We are grateful for the efforts of all NOAA sampling personnel, contributing to the dataset used in this study.

The service charges for this open access publication have been covered by the Max Planck Society.

Edited by: B. N. Duncan

\section{References}

Andreae, M. O. and Merlet, P.: Emission of trace gases and aerosols from biomass burning, Global Biogeochem. Cy., 15, 955-966, 2001.

Arnold, S. R., Chipperfield, M. P., and Blitz, M.: A threedimensional model study of the effect of new temperaturedependent quantum yields for acetone photolysis, Geophys. Res. Lett., 110, D22305, doi:10.1029/2005JD005998, 2005.

Atkinson, R.: Atmospheric chemistry of VOCs and $\mathrm{NO}_{\mathrm{x}}$, Atmos. Environ., 34, 2063-2101, 2000.

Bey, I., Jacob, D. J., Yantosca, R. M., Logan, J. A., Field, B. D., Fiore, A. M., Li, Q., Liu, H. Y., Mickley, L. J., and Schultz, M. G.: Global modeling of tropospheric chemistry with assimilated meteorology: Model description and evaluation, J. Geophys. Res., 106, 23073-23095, 2001.

Blake, D. and Rowland, S.: Urban leakage of liquefied petroleum gas and its impact on Mexico City air quality, Science, 269, 953956, 1995.

Blake Jr., D. R., T. S., T.-Y-Chen, Whipple, W., and Rowland, F. S.: Effects of biomassburning on summertime nonmethane hydrocarbon concentrationsin the Canadian wetlands, J. Geophys. Res., 99, 1699-1719, 1993.

Blake, N., R., B. D., Sive, B., Ketzenstein, A. S., Meinardi, S., Wingenter, O., Atlas, E. L., Flocke, F., Ridley, B. A., and Sherwood, F.: The seasonalevolution of NMHCs and light alkyl nitrates at mniddle to high northern latitudes during TOPSE, J. Geophys. Res., 108, 8359, doi:10.1129/2001JD001467, 2003.

Blitz, M., Heard, D., Pilling, M., Arnold, S. R., and Chipperfield, M. P.: Pressure and temperature-dependent quantum yields for the photodissocuation od acetone between 279 and $327.5 \mathrm{~nm}$, Geophys. Res. Lett., 31, L06111, doi:10.1029/2003GL018793, 2004. 
Bozzano, R., Siccardi, A., Schiano, M. E., Borghini, M., and Castellari, S.: Comparison of ECMWF surface meteorology and buoy observations in the Ligurian Sea, Ann. Geophys., 22, 317-330, doi:10.5194/angeo-22-317-2004, 2004.

Broadgate, W. J., Liss, P. S., and Penkett, S. A.: Seasonal emissions of isoprene and other reactive hydrocarbon gases from the ocean, Geophys. Res. Lett., 24, 2675-2678, 1997.

Brühl, C., Pöschl, U., Crutzen, P. J., and Steil, B.: Acetone and PAN in the upper troposphere: impact on ozone production from aircraft emissions, Atmos. Environ., 34, 3931-3938, 2000.

Brunner, D., Staehelin, J., Rogers, H. L., Köhler, M. O., Pyle, J. A., Hauglustaine, D., Jourdain, L., Berntsen, T. K., Gauss, M., Isaksen, I. S. A., Meijer, E., van Velthoven, P., Pitari, G., Mancini, E., Grewe, G., and Sausen, R.: An evaluation of the performance of chemistry transport models by comparison with research aircraft observations. Part 1: Concepts and overall model performance, Atmos. Chem. Phys., 3, 1609-1631, doi:10.5194/acp-31609-2003, 2003.

Cardelino, C. A. and Chameides, W. L.: Natural hydrocarbons, urbanization, and urban ozone, J. Geophys. Res., 95, 1397113979, 1990.

Daescu, D., Sandu, A., and Carmichael, G.: Direct and Adjoint Sensitivity Analysis of Chemical Kinetic Systems with KPP: II - Validation and Numerical Experiments, Atmos. Environ., 37, 5097-5114, 2003.

Damian, V., Sandu, A., Damian, M., Potra, F., and Carmichael, G.: The Kinetic PreProcessor KPP - A Software Environment for Solving Chemical Kinetics, Computers and Chemical Engineering, 26, 2002.

Emmons, L. K., Hauglustaine, D. A., Müller, J.-F., Carroll, M. A., Brasseur, G. P., Brunner, D., Staehelin, J., Thouret, V., and Marenco, A.: Data composites of airborne observations of tropospheric ozone and its precursors, J. Geophys. Res., 105, $20497-$ 20538, 2000.

Etiope, G. and Ciccioli, P.: Earth's Degassing: A Missing Ethane and Propane Source, Science, 323, p. 478, 2009.

Folberth, G. A., Hauglustaine, D. A., Lathière, J., and Brocheton, F.: Interactive chemistry in the Laboratoire de Mtorologie Dynamique general circulation model: model description and impact analysis of biogenic hydrocarbons on tropospheric chemistry, Atmos. Chem. Phys., 6, 2273-2319, doi:10.5194/acp-62273-2006, 2006.

Folkins, I. and Chatfield, R.: Impact of acetone on ozone production and $\mathrm{OH}$ in the upper troposphere at high NOx, J. Geophys. Res., 105, 11585-11599, 2000.

Friedrich, R. and Obermeier, A.: Anthropogenic emissions of volatile organic compounds, Academic, San Diego, California, 2-38, 1999.

Gautrois, M., Brauers, T., Koppmann, R., Rohrer, F., Stein, O., and Rudolph, J.: Seasonal variability and trends of volatile organic compounds in the lower polar troposphere, J. Geophys. Res., 108, 4393, doi:10.1029/2002JD002765, 2003.

Goldan, P. D., Kuster, W., Fehsenfeld, F., and Montzka, S.: Hydrocarbon measurements in the southeastern United States: The Rural Oxidants in the Southern Environment (ROSE) program 1990, J. Geophys. Res., 100, 35945-35963, 1995.

Goldan, P. D., Parrish, D. D., Kuster, W. C., Trainer, M., McKeen, S., Holloway, J., Jobson, B., Sueper, D., and Fehsenfeld: Airborne measurements of isoprene, $\mathrm{CO}$, and anthropogenic hydrocarbons and their implications, J. Geophys. Res., 105, 9091-9105, 2000.

Guenther, A., Hewitt, C. N., Erickson, D., Fall, R., Geron, C., Graedel, T., Harley, P., Klinger, L., Lerdau, M., McKay, W. A., Pierce, T., Scholes, B., Steinbrecher, R., Tallamraju, R., Taylor, J., and Zimmerman, P.: A global model of natural volatile organic compound emissions, J. Geophys. Res., 100, 8873-8892, 1995.

Guenther, A., Geron, C., Pierce, T., Lamb, B., Harley, P., and Fall, R.: Natural emissions of non-methane volatile organic compounds, carbon monoxide, and oxides of nitrogen from North America, Atmos. Environ., 34, 2205-2230, 2000.

Gupta, M. L., Cicerone, R. J., Blake, D. R., Rowland, F. S., and Isaksen, I. S. A.: Global atmospheric distributions and source strengths of light hydrocarbons and tetrachloroethene, J. Geophys. Res., 103, 28219-28235, 1998.

Haas-Laursen, D. and Hartley, D.: Consistent sampling methods for comparing models to $\mathrm{CO}_{2}$ flask data, J. Geophys. Res., 102, 19059-19071, 1997.

Hagerman, L. M., Aneja, V. P., and Lonneman, W. A.: Characterization of non-methane hydrocarbons in the rural southeast United States, Atmos. Environ., 23, 4017-4038, 1997.

Helmig, D., Tanner, D., Honrath, R., Owen, R., and Parrish, D.: Nonmethane hydrocarbons at Pico Mountain, Azores: 1. Oxidation chemistry in the North Atlantic region, J. Geophys. Res., 113, D20S91, doi:10.1029/2007JD008930, 2008.

Houweling, S., Dentener, F., and Lelieveld, J.: The impact of nonmethane hydrocarbon compounds on tropospheric photochemistry, J. Geophys. Res., 103, 10673-10696, 1998.

Jacob, D., Field, B., Jin, E., Bey, I., Li, Q., Logan, J., and Yantosca, R.: Atmospheric budget of acetone, J. Geophys. Res., 107, 4100, doi:10.1029/2001JD000694, 2002.

Jaeglé, L., Jacob, D. J., Brune, W. H., and Wennberg, P. O.: Chemistry of $\mathrm{HO}_{x}$ radicals in the upper troposphere, Atmos. Environ., 35, 469-489, 2001.

Jeuken, A., Siegmund, P., Heijboer, L., Feichter, J., and Bengtsson, L.: On the potential assimilating meteorological analyses in a global model for the purpose of model validation, J. Geophys. Res., 101, 16939-16950, 1996.

Jobson, B. T., Wu, Z., Niki, H., and Barrie, L. A.: Seasonal trends of isoprene, alkanes, and acetylene at a remote boreal site in Canada, J. Geophys. Res., 99, 1589-1599, 1994.

Jöckel, P., Sander, R., Kerkweg, A., Tost, H., and Lelieveld, J.: Technical Note: The Modular Earth Submodel System (MESSy) - a new approach towards Earth System Modeling, Atmos. Chem. Phys., 5, 433-444, doi:10.5194/acp-5-433-2005, 2005.

Jöckel, P., Tost, H., Pozzer, A., Brühl, C., Buchholz, J., Ganzeveld, L., Hoor, P., Kerkweg, A., Lawrence, M. G., Sander, R., Steil, B., Stiller, G., Tanarhte, M., Taraborrelli, D., van Aardenne, J., and Lelieveld, J.: The atmospheric chemistry general circulation model ECHAM5/MESSy1: consistent simulation of ozone from the surface to the mesosphere, Atmos. Chem. Phys., 6, 50675104, doi:10.5194/acp-6-5067-2006, 2006.

Kerkweg, A., Buchholz, J., Ganzeveld, L., Pozzer, A., Tost, H., and Jöckel, P.: Technical Note: An implementation of the dry removal processes DRY DEPosition and SEDImentation in the Modular Earth Submodel System (MESSy), Atmos. Chem. Phys., 6, 4617-4632, doi:10.5194/acp-6-4617-2006, 2006a. 
Kerkweg, A., Sander, R., Tost, H., and Jöckel, P.: Technical note: Implementation of prescribed (OFFLEM), calculated (ONLEM), and pseudo-emissions (TNUDGE) of chemical species in the Modular Earth Submodel System (MESSy), Atmos. Chem. Phys., 6, 3603-3609, doi:10.5194/acp-6-3603-2006, 2006b.

Kerkweg, A., Jöckel, P., Pozzer, A., Tost, H., Sander, R., Schulz, M., Stier, P., Vignati, E., Wilson, J., and Lelieveld, J.: Consistent simulation of bromine chemistry from the marine boundary layer to the stratosphere - Part 1: Model description, sea salt aerosols and $\mathrm{pH}$, Atmos. Chem. Phys., 8, 5899-5917, doi:10.5194/acp-85899-2008, 2008a.

Kerkweg, A., Jöckel, P., Warwick, N., Gebhardt, S., Brenninkmeijer, C. A. M., and Lelieveld, J.: Consistent simulation of bromine chemistry from the marine boundary layer to the stratosphere - Part 2: Bromocarbons, Atmos. Chem. Phys., 8, 5919-5939, doi:10.5194/acp-8-5919-2008, 2008b.

Kesselmeier, J. and Staudt, M.: Biogenic Volatile Organic Compounds (VOC): An Overview on Emission, Physiology and Ecology, J. Atmos. Chem., 33, 23-88, 1999.

Lee, H. B., Munger, J., Steven, C., and Goldstein, A. H.: Anthropogenic emissions of nonmethane hydrocarbons in the northeastern United Sates: Measured seasonal variations from 1992-1996 and 1999-2001, J. Geophys. Res., 111, D20307, doi:10.1029/2005JD006172, 2006.

Lelieveld, J., Brühl, C., Jöckel, P., Steil, B., Crutzen, P. J., Fischer, H., Giorgetta, M. A., Hoor, P., Lawrence, M. G., Sausen, R., and Tost, H.: Stratospheric dryness: model simulations and satellite observations, Atmos. Chem. Phys., 7, 1313-1332, doi:10.5194/acp-7-1313-2007, 2007.

Logan, J. A.: Tropospheric ozone: Seasonal behavior, trends, and anthropogenic influence, J. Geophys. Res., 90, 10463-10482, 1985.

Marandino, C., De Bruyn, W., Miller, S., Prather, M., and Saltzmann, E.: Oceanic uptake and the global atmospheric acetone budget, Geophys. Res. Lett., 32, L15806, doi:10.1029/2005GL023285, 2005.

McKeen, S. A., Gierczak, T., Burkholder, J. B., Wennberg, P. O., Hanisco, T. F., Keim, E. R., Gao, R.-S., Liu, S. C., Ravishankara, A. R., and Fahey, D. W.: The photochemistry of acetone in the upper troposphere: A source of odd-hydrogen radicals, Geophys. Res. Lett., 24, 3177-3180, 1997.

McLaren, R., Singleton, D. L., Lai, J. Y., Khouw, B., Singer, E., Wu, Z., and Niki, H.: Analysis of motor vehicle sources and their contribution to ambient hydrocarbon distributions at urban sites in Toronto during the Southern Ontario Oxidants Study, Atmos. Environ., 30, 2219-2232, 1996.

Middleton, P., Stockwell, W. R., and Carter, W. P. L.: Aggregation and analysis of volatile organic compound emissions for regional modeling, Atmos. Environ., 24A, 1107-1133, 1990.

Millet, D. B., Guenther, A., Siegel, D. A., Nelson, N. B., Singh, H. B., de Gouw, J. A., Warneke, C., Williams, J., Eerdekens, G., Sinha, V., Karl, T., Flocke, F., Apel, E., Riemer, D. D., Palmer, P. I., and Barkley, M.: Global atmospheric budget of acetaldehyde: 3-D model analysis and constraints from in-situ and satellite observations, Atmos. Chem. Phys., 10, 3405-3425, doi:10.5194/acp-10-3405-2010, 2010.

Moxim, W. J., Levy, H., and Kasibhatla, P. S.: Simulated global tropospheric PAN: Its transport and impact on $\mathrm{NO}_{\mathrm{x}}, \mathrm{J}$. Geophys. Res., 101, 12621-12638, 1996.
Müller, J.-F. and Brasseur, G.: IMAGES: A three-dimensional chemical transport model of the global troposphere, J. Geophys. Res., 100, 16445-16490, 1995.

Neeb, P.: Structure-Reactivity Based Estimation of the Rate Constants for Hydroxyl Radical Reactions with Hydrocarbons, J. Atmos. Chem., 35, 295-315, 2000.

Olivier, J. G. J., Bouwman, A. F., van der Maas, C. W. M., Berdowski, J. J. M., Veldt, C., Bloos, J. P. J., Visschedijk, A. J. J., Zandveld, P. Y. J., and Haverlag, J. L.: Description of EDGAR Version 2.0: A set of global inventories of greenhouse gases and ozone-depleting substances for all anthrophogenic and most natural sources on a per country $1^{\circ} \times 1^{\circ}$ grid, RIVM Rep. 771060002 , Rijksinstituut, Bilthoven, Netherlands, 1996.

Olivier, J. G. J., Bloos, J. P. J., Berdowski, J. J. M., Visschedijk, A. J. H., and Bouwman, A. F.: A 1990 global emission inventory of anthropogenic sources of carbon monoxide on $1^{\circ} \times 1^{\circ}$ developed in the framework of EDGAR/GEIA, Chemosphere, 1 , 1-17, 1999.

Parrish, D., Stohl, A., Forster, C., Atlas, E., Blake, D., Goldan, P., Kuster, W. C., and de Gouw, J.: Effects of mixing on evoultion of hydrocarbon ratios in the troposphere, J. Geophys. Res., 112, D10S34, doi:10.1029/2006JD007583, 2007.

Plass-Dülmer, C., Koppmann, R., Ratte, M., and Rudolph, J.: Light non-methane hydrocarbons in seawater, Global Biogeochem. Cy., 9, 79-100, 1995.

Poisson, N., Kanakidou, M., and Crutzen, P. J.: Impact of nonmethane hydrocarbons on tropospheric chemistry and the oxidizing power of the global troposphere: 3-dimensional modelling results, J. Atmos. Chem., 36, 157-230, 2000.

Pollmann, J., Helmig, D., Hueber, J., Plass-Dülmer, C., and Tans, P.: Sampling,storage and analysis $C_{2}-C_{7}$ non-methane hydrocarbons from the US National Oceanic and Atmospheric Administration Cooperative Air Sampling Network glass flasks, J. Chromatogr. A, 1188, 75-87, 2008.

Potter, C., Klooster, S., Bubenheim, D., Singh, H. B., and Myneni, R.: Modeling terrestrial biogenic sources of oxygenated organic emissions, Earth Interaction, 7, 1-15, 2003.

Pozzer, A., Jöckel, P., Tost, H., Sander, R., Ganzeveld, L., Kerkweg, A., and Lelieveld, J.: Simulating organic species with the global atmospheric chemistry general circulation model ECHAM5/MESSy1: a comparison of model results with observations, Atmos. Chem. Phys., 7, 2527-2550, doi:10.5194/acp-72527-2007, 2007.

Pozzer, A., Jöckel, P., and Van Aardenne, J.: The influence of the vertical distribution of emissions on tropospheric chemistry, Atmos. Chem. Phys., 9, 9417-9432, doi:10.5194/acp-9-9417-2009, 2009.

Roberts, J., Jutte, R., Fehsenfeld, F., Albriton, D., and Sievers, R.: Measurements of anthropogenic hydrocarbon concentration ratios in the rural troposphere: Discrimination between background and urban sources, Atmos. Environ., 19, 1945-1950, 1985.

Roeckner, E., Brokopf, R., Esch, M., Giorgetta, M., Hagemann, S., Kornblueh, L., Manzini, E., Schlese, U., and Schulzweida, U.: Sensitivity of simulated climate to horizontal and vertical resolution in the ECHAM5 atmosphere model, J. Climate, 19, 3771-3791, 2006.

Roelofs, G.-J. and Lelieveld, J.: Tropospheric ozone simulation with a chemistry-general circulation model: Influence of higher 
hydrocarbon chemistry, J. Geophys. Res., 105, 22697-22712, 2000.

Rood, R. B.: Numerical advection algorithms and their role in atmospheric transport and chemistry models, Rev. Geophys., 25, 71-100, 1987.

Rudolph, J.: The tropospheric distribution and budget of ethane, J. Geophys. Res., 100, 11369-11381, 1995.

Saito, T., Yokouchi, Y., and Kawamura, K.: Distribution of $\mathrm{C}_{2}-\mathrm{C}_{6}$ hydrocarbons over the western north Pacific and eastern Indian Ocean, Atmos. Environ., 34, 4373-4381, 2000.

Salstein, D., Ponte, R., and Cady-Pereira, K.: Uncertainties in atmospheric surface pressure fields from global analyses, J. Geophys. Res., 113, D14107, doi:10.1029/2007JD009531, 2008.

Sander, R., Kerkweg, A., Jöckel, P., and Lelieveld, J.: Technical note: The new comprehensive atmospheric chemistry module MECCA, Atmos. Chem. Phys., 5, 445-450, doi:10.5194/acp-5445-2005, 2005.

Sandu, A., Daescu, D., and Carmichael, G.: Direct and Adjoint Sensitivity Analysis of Chemical Kinetic Systems with KPP: I - Theory and Software Tools, Atmos. Environ., 37, 5083-5096, 2003.

Saunders, S. M., Jenkin, M. E., Derwent, R. G., and Pilling, M. J.: Protocol for the development of the Master Chemical Mechanism, MCM v3 (Part A): tropospheric degradation of nonaromatic volatile organic compounds, Atmos. Chem. Phys., 3, 161-180, doi:10.5194/acp-3-161-2003, 2003.

Seinfeld, J. H. and Pandis, S.: Atmospheric Chemistry and Physics: From Air Pollution to Climate Change, Wiley-Interscience, 1997.

Sharma, U. K., Kajii, Y., and Akimoto, H.: Seasonal variation of $\mathrm{C}_{2}-\mathrm{C}_{6} \mathrm{NMHCs}$ at Happo, a remote site in Japan, Atmos. Environ., 34, 4447-4458, 2000.

Singh, H., Salas, 1., Chatfield, R., Czech, E., Fried, A., Walega, J., Evans, M., Field, B., Jacob, D., Blake, D., Heikes, B., Talbot, R. andSachse, G., Crawford, J., Avery, M., Sandholm, S., and Fuelberg, H.: Analysis of the atmospheric distriburion, sources, and sinks of oxygenated volatile organic chemicals based in measurements over the Pacific during TRACE-P, J. Geophys. Res., 105(D3), D15S07, doi:10.1029/2003JD003883, 2004.

Singh, H. B. and Zimmermann, P.: Atmospheric distribution and sources of nonmethane hydrocarbons, John Wiley, New York, 1992.

Singh, H. B., O'Hara, D., Herlth, D., Sachse, W., Blake, D. R., Bradshaw, J. D., Kanakidou, M., and Crutzen, P. J.: Acetone in the atmosphere: Distribution, source, and sinks, J. Geophys. Res., 99, 1805-1819, 1994.

Singh, H. B., Kanakidou, M., Crutzen, P. J., and Jacob, D. J.: High concentrations and photochemical fate of oxygenated hydrocarbons in the global troposphere, Nature, 378, 50-54, 1995.

Singh, H. B., Chen, Y., Staudt, A. C., Jacob, D. J., Blake, D. R., Heikes, B. G., and Snow, J.: Evidence from the Pacific troposphere for large global sources of oxygenated organic compounds, Nature, 410, 1078-1081, 2001.

Singh, H. B., Tabazadeh, A., Evans, M. J., Field, B. D., Jacob, D. J., Sachse, G., Crawford, J. H., Shetter, R., and Brune, W. H.: Oxygenated volatile organic chemicals in the oceans: Inferences and implications based on atmospheric observations and air-sea exchange models, Geophys. Res. Lett., 30, 1862, doi:10.1029/2003GL017933, 2003.
Singh, H. B., Salas, L. J., Ridley, B. A., Shetter, J. D., Donahue, N. M., Fehsenfeld, F. C., Fahey, D. W., Parrish, D. D., Williams, E. J., Liu, S. C., Hübler, G., and Murphy, P. C.: Relationship between peroxyacetyl nitrate (PAN) and nitrogen oxides in the clean troposphere, Nature, 318, 347-349, 1985.

Spivakovsky, C. M., Logan, J. A., Montzka, S. A., Balkanski, Y. J., Foreman-Fowler, M., Jones, D. B. A., Horowitz, L. W., Fusco, A. C., Brenninkmeijer, C. A. M., Prather, M. J., Wofsy, S. C., and McElroy, M. B.: Three-dimensional climatological distribution of tropospheric $\mathrm{OH}$ : Update and evaluation, J. Geophys. Res., 105, 8931-8980, 2000.

Swanson, A., Blake, N., Atlas, E., Flocke, F., Blake, D. R., and Sherwood, F.: Seasonal variation of $C_{2}-C_{4}$ nonmethane hydrocarbons and $C 1-C 4$ alkyl nitrates at the Summit research station in Greenland, J. Geophys. Res., 108, 4065, doi:10.1129/2001JD001445, 2003.

Taddei, S., Toscano, P., Gioli, B., Matese, A., Miglietta, F., Vaccari, F. P., Zaldei, A., Custer, T., and Williams, J.: Carbon Dioxide and Acetone AirSea Fluxes over the Southern Atlantic, Environ. Sci. Technol., 43, 5218-5222, 2009.

Taylor, K.: Summarizing multiple aspects of model performance in a single diagram, J. Geophys. Res., 106, 7183-7192, 2001.

Tost, H., Jöckel, P., Kerkweg, A., Sander, R., and Lelieveld, J.: Technical note: A new comprehensive SCAVenging submodel for global atmospheric chemistry modelling, Atmos. Chem. Phys., 6, 565-574, doi:10.5194/acp-6-565-2006, 2006.

Tyndall, G. S., Staffelbach, T. A., Orlando, J. J., and Calvert, J. G.: Rate coefficients for the reactions of $\mathrm{OH}$ radicals with methylglyoxal and acetaldehyde, Int. J. Chem. Kinetics, 27, 1009-1020, 1995.

Tyndall, G. S., Orlando, J. J., Wallington, T. J., Hurley, M. D., Goto, M., and Kawasaki, M.: Mechanism of the reaction of $\mathrm{OH}$ radicals with acetone and acetaldehyde at 251 and 296 K, Phys. Chem. Chem. Phys., 4, 2189-2193, 2002.

van Aardenne, J., Dentener, F., Olivier, J., Peters, J., and Ganzeveld, L.: The EDGAR 3.2 Fast Track 2000 dataset (32FT2000), online available at: http://www.mnp.nl/edgar/model/v32ft2000edgar/ docv32ft2000/, 2005.

van Aardenne, J. A., Dentener, F. J., Olivier, J. G. J., Klein Goldewijk, C. G. M., and Lelieveld, J.: A $1 \mathrm{deg} \times 1 \mathrm{deg}$ resolution data set of historical anthropogenic trace gas emissions for the period 1890-1990, Global Biogeochem. Cy., 15, 909-928, 2001.

Van der Werf, G. R., Randerson, J. T., Collatz, G. J., Giglio, L., Kasibhatla, P. S., Avelino, A., Olsen, S. C., and Kasischke, E.: Continental-scale partitioning of fire emissions during the 1997 2001 El Nino/La Nina period, Science, 303, 73-76, 2004.

von Kuhlmann, R., Lawrence, M. G., Crutzen, P. J., and Rasch, P. J.: A model for studies of tropospheric ozone and nonmethane hydrocarbons: Model description and ozone results, J. Geophys. Res., 108, 4294, doi:10.1029/2002JD002893, 2003a.

von Kuhlmann, R., Lawrence, M. G., Crutzen, P. J., and Rasch, P. J.: A Model for Studies of Tropospheric Ozone and Non-Methane Hydrocarbons: Model Evaluation of Ozone Related Species, J. Geophys. Res., 108, 4729, doi:10.1029/2002JD003348, 2003b.

Wang, Y., Jacob, D. J., and Logan, J. A.: Global simulation of tropospheric $\mathrm{O}_{3}-\mathrm{NO}_{x}$-hydrocarbon chemistry, 1. Model formulation, J. Geophys. Res., 103, 10713-10725, 1998. 
Wennberg, P. O., Hanisco, T. F., Jaeglé, L., Jacob, D., Hintsa, E. J., Lanzendorf, E. J., Anderson, J. G., Gao, R.-S., Keim, E. R., Donnelly, S. G., Negro, L. A. D., Fahey, D. W., McKeen, S. A., Salawitch, R. J., Webster, C. R., May, R. D., Herman, R. L., Proffitt, M. H., Margitan, J. J., Atlas, E. L., Schauffler, S. M., Flocke, F., McElroy, C. T., and Bui, T. P.: Hydrogen radicals, nitrogen radicals, and the production of $\mathrm{O}_{3}$ in the upper troposphere, Science, 279, 49-53, 1998.
World Meteorological Organization, W.: A WMO/GAW expert workshop on global long-term measurements of volatile organic compounds (VOCs), Tech. rep., WMO Rep. 171, Geneva, Switzerland, 2007. 